\title{
Ecohydrology and flood risk management under climate vulnerability in relation to the sustainable development goals (SDGs): a case study in Nagaa Mobarak Village, Egypt
}

\author{
Marwa M. Aly ${ }^{1} \cdot$ Neveen H. Refay ${ }^{2} \cdot$ Hoda Elattar $^{3} \cdot$ Karim M. Morsy ${ }^{4}$. \\ Erick R. Bandala ${ }^{5}$ Samir A. Zein ${ }^{1} \cdot$ Mohamed K. Mostafa $^{2}$
}

Received: 30 September 2021 / Accepted: 17 January 2022 / Published online: 9 February 2022 (C) The Author(s) 2022

\begin{abstract}
This article aims to provide a thorough assessment of water quality and quantity incorporating the estimation of future patterns as a result of climate change from economic, environmental and social perspectives. Its scope extends from studying the physical parameters and rainfall patterns to maintaining an environmental flow with a better water quality using ecohydrological techniques. The village of Nagaa Mobarak in Souhag, Egypt, is taken as a case study being in a critical location that is vulnerable to flash floods. This paper managed to quantify change in water quantity and quality due to the impacts of flash floods and climate change. Several traditional engineering alternatives are proposed for flood management such as constructing a dam, a storage pond and a routing channel to the nearest water body; as well as non-traditional ecohydrological alternatives such as constructing a dam with vegetated foreshore, natural levees and constructed wetlands. The results of applying these methods for our case study showed that a hybrid solution that employs both traditional and non-traditional solutions for flood management is optimal. A constructed wetland along a section of the constructed channel for diverting flow into the Nagaa Hammade Canal would decrease the runoff volume and peak time so that the capacity of the Canal is not exceeded in a flood event and purifies the incoming stormwater improving its quality and the health of the ecosystem within the canal. Moreover, our proposed approach was investigated and found to target 10 out of the 17 UN SDGs.
\end{abstract}

Keywords Climate change $\cdot$ Ecohydrology $\cdot$ Nature-based solutions $\cdot$ Flood risk management $\cdot$ Hydrological modeling $\cdot$ SDGs $\cdot$ Structural flood management

Mohamed K. Mostafa

m_khaled@buc.edu.eg

1 Faculty of Engineering-Mataria, Helwan University, Helwan 11795, Egypt

2 Faculty of Engineering and Technology, Badr University in Cairo (BUC), Cairo 11829, Egypt

3 Faculty of Behavioral, Management and Social Sciences, University of Twente,

7522 NB Enschede, The Netherlands

4 Ministry of Environment, Cairo 11728, Egypt

5 Division of Hydrologic Sciences, Desert Research Institute, Las Vegas, NV, USA 


$\begin{array}{ll}\text { Abbreviations } \\ \text { AIC } & \text { Akaike Information Criterion } \\ \text { CFSR } & \text { Climate Forecast System Reanalysis } \\ \text { CN } & \text { Curve number } \\ \text { DEM } & \text { Digital elevation model } \\ \text { EPA } & \text { Environmental Protection Agency } \\ \text { EWE } & \text { Extreme weather events } \\ \text { FAO } & \text { Food and Agriculture Organization } \\ \text { GG } & \text { Generalized gamma } \\ \text { HEC } & \text { Hydrologic Engineering Center } \\ \text { HMS } & \text { Hydrologic Modeling System } \\ \text { Hyfran-plus } & \text { Hydrological Frequency Analysis Plus } \\ \text { NASA } & \text { National Aeronautics and Space Administration } \\ \text { NOAA } & \text { National Oceanic and Atmospheric Administration } \\ \text { NRCS } & \text { Natural Resources Conservation Service } \\ \text { RAS } & \text { River Analysis System } \\ \text { SCS } & \text { Soil Conservation Service } \\ \text { SRTM } & \text { Shuttle Radar Topography Mission } \\ \text { SWMM } & \text { Storm Water Management Model } \\ \text { TMPA } & \text { TRMM Multi-Satellite Precipitation Analysis } \\ \text { TRMM } & \text { Tropical Rainfall Measuring Mission } \\ \text { UN SDG } & \text { United Nations Sustainable Development Goals } \\ \text { USDA } & \text { United States Department of Agriculture } \\ \text { USGS } & \text { United States Geological Survey } \\ \text { UTM } & \text { Universal Transverse Mercator } \\ \text { VT Builder } & \text { Virtual Tour Builder } \\ \text { WMS } & \text { Watershed Modeling System } \\ & \end{array}$

\section{Introduction}

Flash floods are dangerous because they strike with no advance warning after rainfall events (El-Afandi and Morsy 2020; Fathy et al. 2019; Atwa 2020). They threaten the lives and livelihoods of people as well as their assets and properties (Parvin et al. 2016; Abdeldayem et al. 2020; Kumar et al. 2018). Flash floods intensities and the risk of their occurrence are related to several factors, including rainfall intensity and distribution, soil type and water content, and vegetation type in the catchment area (U.S. Department of Commerce 2015), so mainly precipitation, geology and topography data.

Climate change plays a significant role in flash floods because the warmer atmosphere holds and releases more water, resulting in an increased frequency and intensity of storms (Hettiarachchi et al. 2018). Because of climate change, the incidence of flash flood in Egypt has become more frequent, causing loss of life, destruction of agricultural lands, and property damage (Mashaly and Ghoneim 2018; Youssef and Hegab 2019; Prama et al. 2020). Additionally, the country is currently facing water scarcity challenges because of rapid population growth and reduced river flow, which will inevitably result from the construction of the Grand Ethiopian Renaissance Dam (Abdelhafez et al. 2020; Yassen et al. 2020; Abdelrady et al. 2020; Morsy et al. 2020a, b; Morsy et al. 2021). To alleviate these effects, developing a national plan for sustainable flood management is essential to protecting areas 
and lives from flood danger, maximizing stormwater benefits, and redirecting runoffs into the nearest surface water system for irrigation and groundwater recharge (Mostafa et al. 2016; Wakode et al. 2018; Spiliotis and Skoulikaris 2019; Freni and Liuzzo et al. 2019; Rajasekhar et al. 2020 ;Golian et al. 2020; Ostad-Ali-Askari et al. 2019).

Traditional engineering approaches are to thank for protecting human life from natural threats from wild animals to natural hazards such as floods. Of the traditional approaches for flash flood risk reduction, structural measures (e.g., ditches, embankments, diversion channels, dikes, dams, culverts, and ponds) are considered the most efficient for controlling flash floods (Kumar et al. 2017; Zhu and Chen 2017; Kim et al. 2005; Destro et al. 2018; Sikorska et al. 2018; Kundzewicz et al. 2019). Selecting the most suitable protection method depends on site-specific factors, such as catchment size, rainfall intensity, and the runoff-generating process (Sikorska et al. 2018). However, structural measures are only applicable over the short term because their efficiency decreases over the long term, usually because of land-use change and unplanned development within the flood-protected areas (Shah et al. 2018; Di Baldassarre et al. 2018).

Non-traditional structural flood protection measures have recently gained research interest. Those measures rely on natural systems and ecosystem services, as well as ecohydrology concepts included within the nature-based solutions (Cohen-Shacham et al. 2016; Zalewski et al. 1997; Nafchi et al. 2021). Nature-based solutions (NBS) address a variety of environmental, social, and economic challenges in sustainable ways (European Commission 2015). The solutions are inspired by, supported by, or copied from nature, using and enhancing existing solutions to challenges and exploring novel applications. The NBSs are aligned with the United Nations Sustainable Development Goals (SDGs) (United Nations 2015) and serve as the three main pillars of sustainability that consider people well-being, ecosystem vitality, and economic feasibility (Matute et al. 2016; Scheres and Schüttrumpf 2019). Similarly, flood protection measures and especially nature-based flood protection measures support the achievement of the SDGs, where they target specific indicators especially in goals six on water management and eleven of resilient cities (United Nations 2015).

Numerous researchers have explored strategies for flood management. Regrettably, recent studies consistently ignore the effects of climate change on water quality while developing flood risk management strategies (Abd-El Monsef 2018; Abdulrazzak et al. 2019; Abdeldayem et al. 2020; Fatahi Nafchi et al. 2021; Hafshejani et al. 2019), which is particularly common in developing countries because of a lack of financial resources. This lack in quality is commonly caused by increased precipitation washing away more pollution to water bodies or by extreme droughts increasing the concentration of pollutants in water bodies (Abd-El Monsef 2018; Abdulrazzak et al. 2019; Abdeldayem et al. 2020).

The goal of this study is to evaluate a flash flood risk management strategy for arid regions that targets the expected water quantity while considering solutions for managing water quality. The novelty of this study is based on addressing the dual effect of climate change on water quantity and quality. Moreover, it highlights the contribution of naturebased flood management methods to the SDGs. The dual impacts of climate change on water quantity and quality in response to flooding illustrate the importance of considering the impacts of climate change on flood scenarios. Data retrieved from the World Meteorological Organization were used to predict changes in the rainfall regime due to climate change, as well as changes in temperature. Hydrological and hydraulic software models were used for flash flood and runoff simulation, flash flood management, and a comparison between the efficiency of three traditional methods (artificial pond, artificial flood channel, and dam) in flood water conservation and cost-effectiveness. Three non-traditional flood 
management methods (natural levees, vegetated foreshores, and wetlands) were also compared based on their capability to prevent water quality deterioration and cost-effectiveness. The selection of these methods was based on their common use in the market as well as suitability for the site. By integrating the two management methods as will further be explained, a holistic management approach was developed to target both water quantity and quality. Therefore, this study can be used as a guideline for flash flood management in regions that share similar conditions. Finally, our holistic ecohydrological approach contribution to the achievement of the SDGs is discussed in a separate section on the basis of it being both ecohydrological and used for flood management.

\section{Materials and methods}

\subsection{Case study area}

Sohag Governorate in Upper Egypt has suffered from the loss of lives and major property damage due to severe flooding events in 1994, 2014, and 2016 (El-Magd et al. 2020). The 1994 flash flood collapsed over 100 homes and destroyed 400 acres of reclaimed lands in Sohag (Ali 2014). Sohag Governorate is located in a mountainous region with most villages directly at the foot of the mountains, which poses a great danger of flash flood to the inhabitants (Yasser 2017). To deal with the problem, Sohag authorities decided to create a comprehensive plan for flood management aimed at protecting areas affected by frequent flash floods (Maqbool 2019; Khalid 2019; Al-Ghwait 2019), including Nagaa Mobarak Village.

Nagaa Mobarak Village is located in the eastern region of Sohag Governorate, Egypt (latitude $26^{\circ} 45^{\prime} 31^{\prime \prime} \mathrm{N}$ to $26^{\circ} 44^{\prime} 45^{\prime \prime} \mathrm{N}$, longitude $31^{\circ} 37^{\prime} 02^{\prime \prime} \mathrm{E}$ to $31^{\circ} 35^{\prime} 44^{\prime \prime} \mathrm{E}$, Fig. 1). The total village area is $4.2 \mathrm{~km}^{2}$ out of which $28 \%$ represents inhabited area, $2 \%$ is unoccupied desert, and $70 \%$ is agricultural area. The soil texture data in the study area obtained

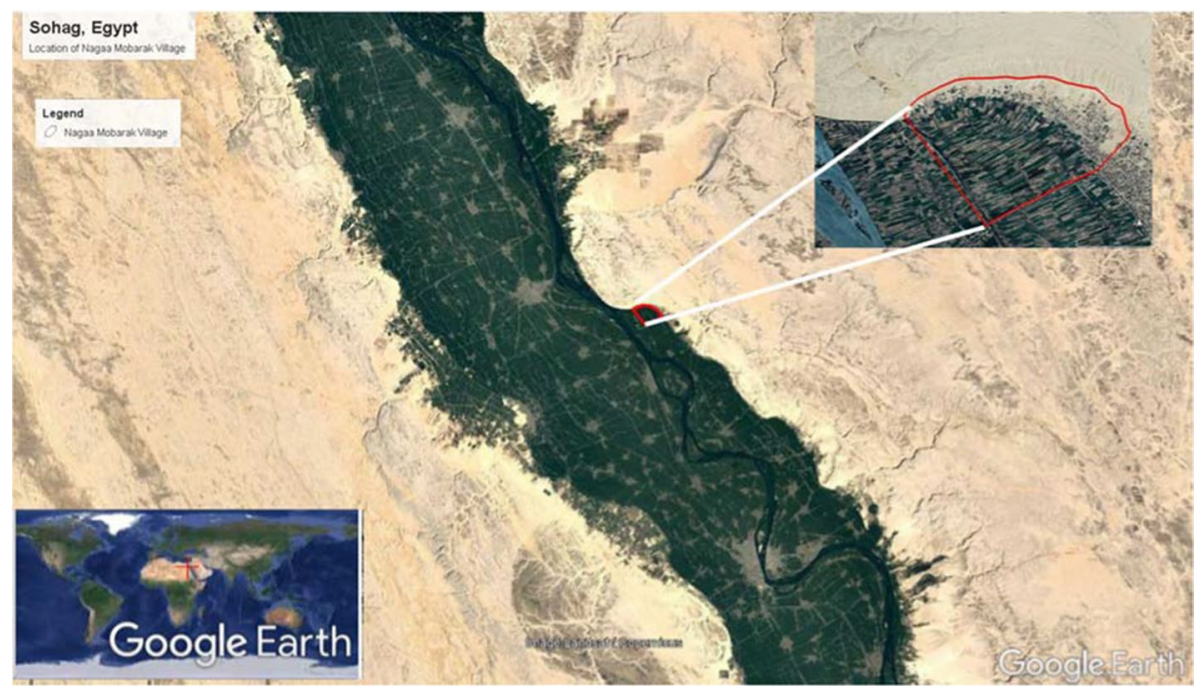

Fig. 1 Location of Nagaa Mobarak Village (the Study Area) 
from the SoilGrids system (ISRIC 2020) determined the area were comprised of sandy clay with gravel classified as group D according to the United States Department of Agriculture (USDA)- Natural Resources Conservation Service (NRCS) (USD 1968). The elevation ranges from 34 to $50 \mathrm{~m}$ above sea level (MASL), and the area is bounded from the east by a limestone plateau with elevations ranging from 59 to 87 MASL. The village is at a high risk of flash floods, especially from the eastern part. Based on the Egyptian governmental data, the village population is 13,000. According to the Köppen climate classification, Nagaa Mobarak Village has a hot desert climate and receives between 25 and $200 \mathrm{~mm}$ of rainfall annually (Laity 2008).

\subsection{Methodology}

The methodology followed in this paper is summarized in Fig. 2 and elaborated on further in the following sections.

\subsubsection{Data Collection}

The topography of the study area and the historical precipitation data play a role in determining the catchment characteristics. The current physical and chemical characteristics of the water are required to understand the baseline situation on water quality and estimate the future situation. Finally, climatic data (including temperature) are required to analyze the impact of climate change on water quality and quantity. Precipitation, topography, and climatic data as well as physical and chemical water characteristics were collected as follows:

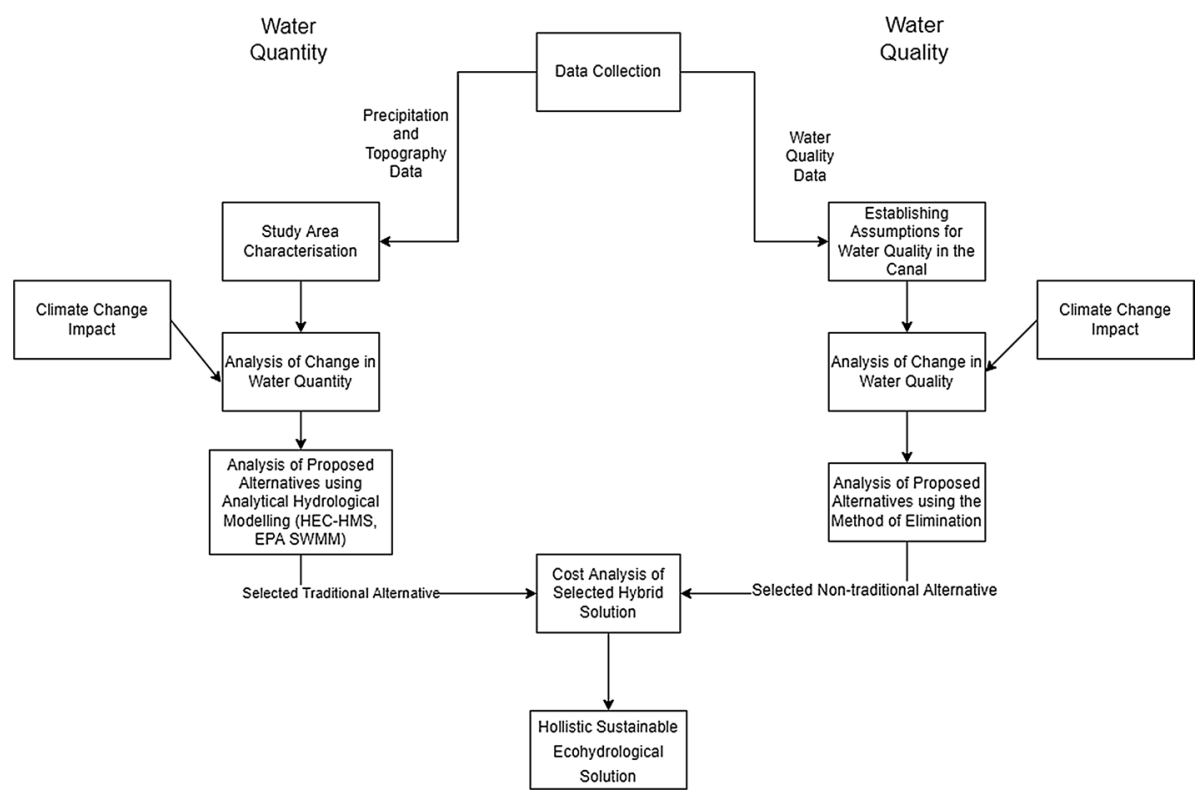

Fig. 2 Methodological framework 
(a) Climate Data. Three datasets were used to collect climate data from the Climate Explorer website of the World Meteorological Organization, namely AR5 CMIP5, CMIP5 ensemble, and CMIP5 one member (Climate Explorer 2020). Two different datasets were obtained from the latter, one for when the risk ratio (RR) was greater than $95 \%$ and one for when it was greater than $99 \%$.

(b) Annual Precipitation Data. Rainfall data (Fig. 2) were obtained from the Tropical Rainfall Measuring Mission (TRMM) satellite and Global Weather Data for Soil \& Water Assessment Tool (SWAT) 2019 (Global Weather Data for SWAT 2020; NASA 2020). The highest value $(83 \mathrm{~mm})$ was considered to be the design basis for water quantity analysis as a conservative measure.

(c) Water Quality Data. Very little is known about water quality data for the Nagaa Hammadi Canal (NHC, Table 1) with the only available information coming from sampling campaigns in 2001 (El-Sheekh 2009) and 2008 (NRI 2008). The time of sample collection is unclear but by comparing the data with data from other water bodies in Egypt, it can be assumed that the measurements were obtained in the winter (Fig. 3).

However, data that are two decades old are unreliable, especially considering the major developments in the country. Therefore, recent water quality data from another waterbody connected to the NHC were used for water quality analysis. Morsy et al. (2020a, b) examined water quality in several Egyptian lakes (e.g., Lakes Maryut, Idku, Burullus, and Manzala), highlighting variations in parameter values across the year. Lake Manzala, which had the lowest dissolved oxygen (DO) and highest biochemical oxygen demand (BOD) and chemical oxygen demand (COD) values, was selected as the basis for the water quality assessment in this study. To ensure a fair comparison of the water quality data, a water quality index (WQI) was determined using the methodology reported by Sanchez et al. (2007). These authors proposed using Eq. (1) as the empirical representation of the WQI:

$$
\mathrm{WQI}=k \frac{\sum_{i} C_{i} P_{i}}{\sum_{i} P_{i}}
$$

where $k$ is a subjective constant with a maximum value 1.0 for apparently good quality water and 0.25 for apparently highly polluted water, $\mathrm{Ci}$ is the normalized value of the parameter, and $\mathrm{Pi}$ is the relative weight assigned to each parameter.

As suggested by Sanchez et al. (2007), the constant k was not considered to avoid subjective evaluation, and the suggested values for $\mathrm{Pi}$ and $\mathrm{Ci}$ are summarized in Table 2. The WQI values from 0 to 25 were ranked as very bad, values ranging from 26 to 50 were bad, values ranging from 51 to 70 were fair, values ranging from 71 to 90 were good, and values ranging from 91 to 100 were excellent. Because of the lack of water quality data, the WQI was estimated using only OD $\left(P_{i}=4\right)$ and temperature $\left(P_{i}=1\right)$. Table 3 summarizes the corresponding water quality parameters at Lake Manzala for different sampling months.

\subsubsection{Data analysis}

For water quantity, analytical tools in hydrological software were used to estimate the impacts of climate change on flooding in the study area. The selection of these analytical tools was done to minimize the model inputs as much as possible given the uncertainty associated with obtaining outdated real-life data, which is the main available data source. Additionally, this study aims at estimating a one-of the worst-case scenario flash flood event analyzing the magnitude of the impact only and proposing conservative 


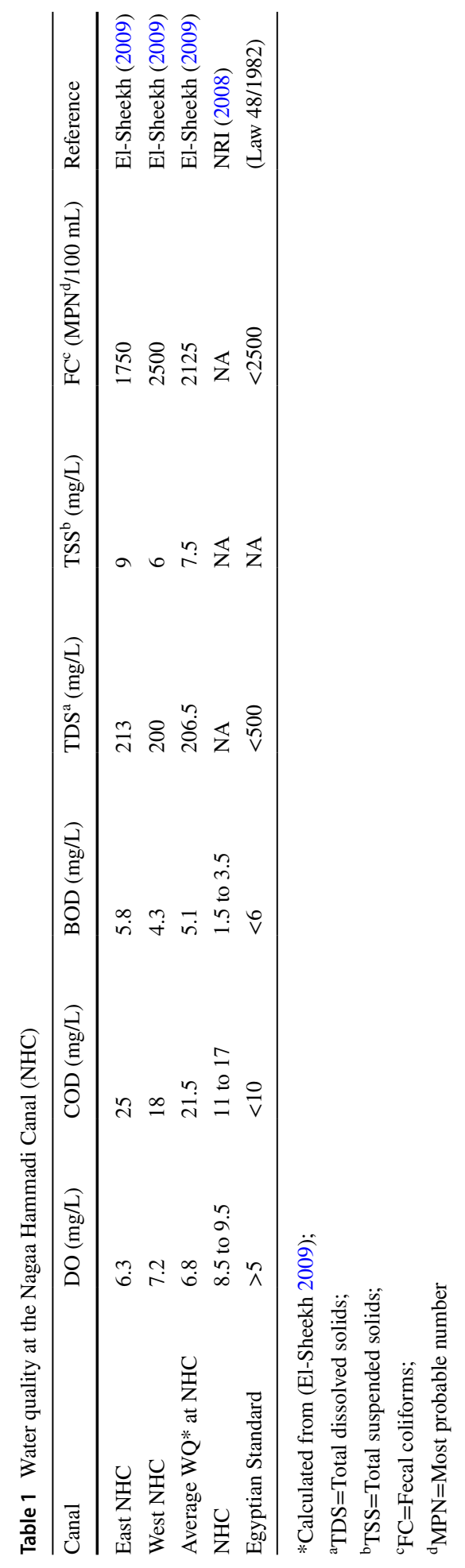




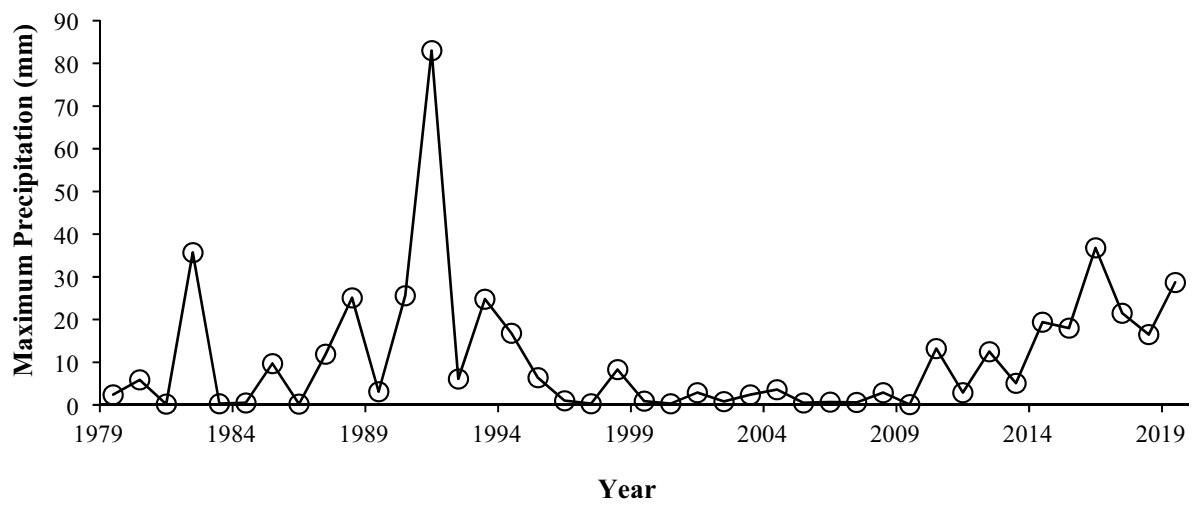

Fig. 3 Annual maximum precipitation from 1998 to 2019 based on TRMM satellite data (NASA 2020)

Table 2 Pi and Ci values for DO and temperature ( modified from Sanchez et al. (2007))

\begin{tabular}{|c|c|c|c|c|c|c|c|c|c|c|c|c|}
\hline \multirow[t]{2}{*}{ Parameter } & \multirow[t]{2}{*}{$P_{i}$} & \multicolumn{11}{|l|}{$C_{i}$} \\
\hline & & 100 & 90 & 80 & 70 & 60 & 50 & 40 & 30 & 20 & 10 & 0 \\
\hline DO & 4 & 7.5 & $>7.0$ & $>6.5$ & $>6.0$ & $>5.0$ & $>4.0$ & $>3.5$ & $>3.0$ & $>2.0$ & $>1.0$ & $<1.0$ \\
\hline Temperature & 1 & $12 / 16$ & $22 / 15$ & $24 / 14$ & $26 / 12$ & $28 / 10$ & $30 / 5$ & $32 / 0$ & $36 /-2$ & $40 /-4$ & $45 /-6$ & $>45 /<-6$ \\
\hline
\end{tabular}

Table 3 Water quality for Lake Manzala (adopted from Morsy et al. $(2020 \mathrm{a}, \mathrm{b}))$

\begin{tabular}{llllll}
\hline Parameter & January & March & June & September & December \\
\hline Temperature $\left({ }^{\circ} \mathrm{C}\right)$ & 15.3 & 22.1 & 32.3 & 33.2 & 17.2 \\
DO (mg/L) & 5.1 & 5.3 & 3.0 & 3.2 & 5.4 \\
pH (unitless) & 8.2 & 8.1 & 8 & 8.5 & 8.7 \\
Turbidity (NTU) & 6.9 & 13.2 & 16.3 & 12.1 & 2.95 \\
TSS (mg/L) & 22 & 18.6 & 74.1 & 71.9 & 62.85 \\
BOD (mg/L) & 15 & 30 & 48.6 & 35 & 13.5 \\
COD (mg/L) & 120 & 240 & 388.8 & 280 & 106.2 \\
WQI & 66 & 66 & 32 & 30 & 68 \\
\hline
\end{tabular}

alternatives to manage the event. Risk assessment methods commonly used in the literature (Lyu et al. 2018, 2020; Lyu et al. 2019a, b, c) are not within the scope of this research as the probability of occurrence is out of boundaries.

The Watershed Modeling System (WMS 11.0) software developed by Aquaveo (Utah, United States) was used for watershed delineation. The Environmental Protection Agency Storm Water Management Model (EPA-SWMM) was used to design the proposed structural element (the routing channel). The Hydrologic Engineering CenterHydrologic Modeling System (HEC-HMS) developed by the U.S. Army Corps of Engineers was used to simulate flash floods to obtain useful data such as the peak discharge flow, time to peak discharge, and runoff volume. 
The terrain surface was represented using a $30 \times 30 \mathrm{~m}$ digital elevation model (DEM) called the Shuttle Radar Topography Mission (SRTM) (Survey 2020). Virtual Terrain Builder (VT Builder) was used to interpolate the missing data in the DEM (Project 2018). The complete DEM retrieved from VT Builder as well as the watershed characteristics (i.e., soil type, curve number $(\mathrm{CN})$, slope) was used by the WMS software for watershed delineation into basins and subbasins, as well as computing accumulated flow and flow directions. The hypothetical Soil Conservation Service (SCS) type II distribution was found to be suitable for deriving the 24-h time distribution during extreme events in the study area (Awadallah et al. 2016, 2017; Romero and Emanuel 2017; El-Sayed 2018). The return period was estimated to be 100 years (Water Resources Publication 2008; Youssef 2016).

The HEC-HMS was used to simulate flash floods in every basin and subbasin in the study area (Hydrologic Engineering Center 2006), which provided details on the peak discharge flow, time to peak discharge, and runoff volume (Dweependra 2008). Finally, EPA SWMM was used for simulating a 100-year return period flash flood using 30-min time steps (U.S. EPA 2020).

Given the complexity of natural processes and the required amounts of high-quality accurate data to be able to model ecohydrological solutions with acceptable results, this study analyzes the methods proposed to safeguard water quality during flash floods using the scientific logical elimination approach based on data collected from the lecture.

\subsection{Contribution to the SDGs}

As mentioned, this research also studies the contribution of hybrid ecohydrological solutions to the achievement of the United Nations (UN) Sustainable Development Goals (SDGs) (United Nations 2015). Through systematically reviewing the description of the UN SDGs, we have identified which standards exactly are supported by our solution. A discussion of the contribution to the SDGs follows presenting and discussing our results and exploring the proposed solution for our case study.

\section{Results and discussion}

\subsection{Study area characterization}

Figure 4 shows the results of the full catchment delineation study, which were obtained following the same approach reported by Abdeldayem et al. (2020), Ramakrishnan et al. (2009), and Durga Rao et al. (2003). During the design of the proposed flood management solution, the collection site was assumed to be initially empty. Rainwater infiltration and evaporation were also considered during channel design. Based on the weather conditions in the study area, the evapotranspiration rate was assumed to be $5 \mathrm{~mm} /$ day (Baldi et al. 2020). Subsurface storage depends mainly on the soil type, which is classified as cultivated sandy clay with an infiltration rate of $6.5 \mathrm{~mm} / \mathrm{h}$ in the study area (Mangala et al. 2016).

As mentioned, the DO contents of Egyptian water bodies under current weather conditions and water temperatures were obtained from the study by Morsy et al. (2020a, b). The DO concentration was used because of its simple relation to water temperature. Water quality at Lake Manzala was considered representative of the NHC because it exhibited the lowest DO concentration. However, because temperatures at Lake Manzala are for water (Morsy et al. 2020a, b) and temperatures predicted by the model are for air, the relationship 

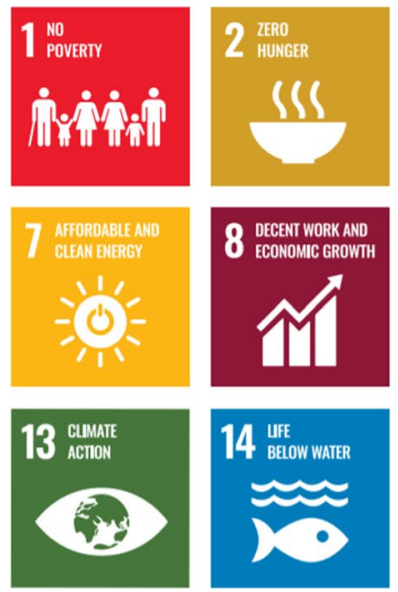
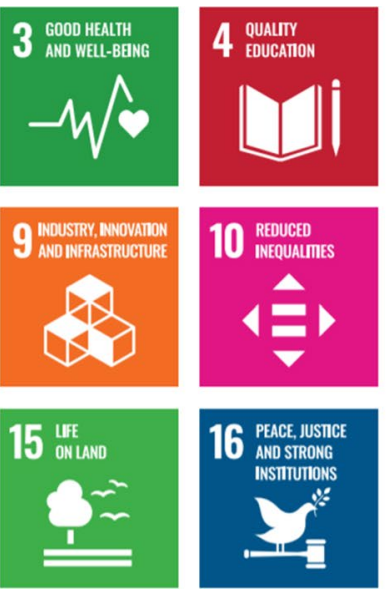
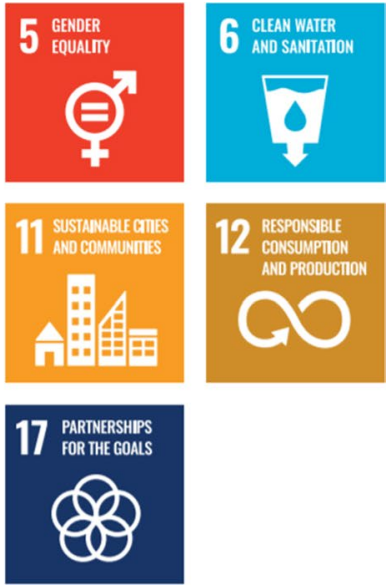

Fig. 4 The United Nations Sustainable Development Goals

between water and air temperatures must be determined. Morrill et al. (2005) identified a relationship between water and air temperatures for diverse streams. Their results show that a $0.6{ }^{\circ} \mathrm{C}$ increase in water temperature occurs for each $1{ }^{\circ} \mathrm{C}$ increase in air temperature given the higher water heat capacity. It is estimated that every $1.7^{\circ} \mathrm{C}$ increase in air temperature corresponds to $1{ }^{\circ} \mathrm{C}$ increase in water temperature, which is associated with a $0.25 \mathrm{mg} / \mathrm{L}$ decrease in DO content. Therefore, a $1.8{ }^{\circ} \mathrm{C}$ increase in water temperature corresponds to a $3{ }^{\circ} \mathrm{C}$ increase in air temperature (Morrill et al. 2005) and a $0.45 \mathrm{mg} / \mathrm{L}$ decrease in DO concentration. These estimates were used to predict any decreases in the DO concentration that reach critical levels and endanger the stream ecology. By identifying these events, mitigation measures can be implemented to protect water quality from the impacts of climate change, which are needed considering the expected decrease in fresh water quantities in Egypt associated with climate change (Omar et al. 2021).

\subsection{Climate change analysis}

Climate change is associated with increased temperatures and changes in precipitation regimes (Orlob et al. 1996). These two factors lead to variations in water quantity and quality from usual conditions (Morsy et al. 2017; Moss et al. 2011). For example, an increase in precipitation leads to an increase in water nutrients, which encourages harmful algal blooms and depletes DO concentrations in water. Similarly, increased temperatures increase sediment and soil mineralization that spike nutrient loads, which increases the risk of harmful algal blooms that in turn consume DO (Ostad-Ali-Askari et al. 2020). Quantifying nutrient content in water is complex because it involves considering multiple factors, from air quality to land use in the catchment area (Jeppesen et al. 2009). The DO concentration was selected as a proxy for water quality because this parameter is largely directly affected by temperature (Mackay and Fleming 1969).

Figures 5, 6, and 7 show the expected precipitation variation using different risk ratios (RRs) obtained from Coupled Model Intercomparison Project - Phase 5 (CMIP5) and the expected change in air temperature due to climate change from the AR5 CMIP dataset. As shown in Fig. 5, an increase in precipitation is expected in the study areas for all scenarios 


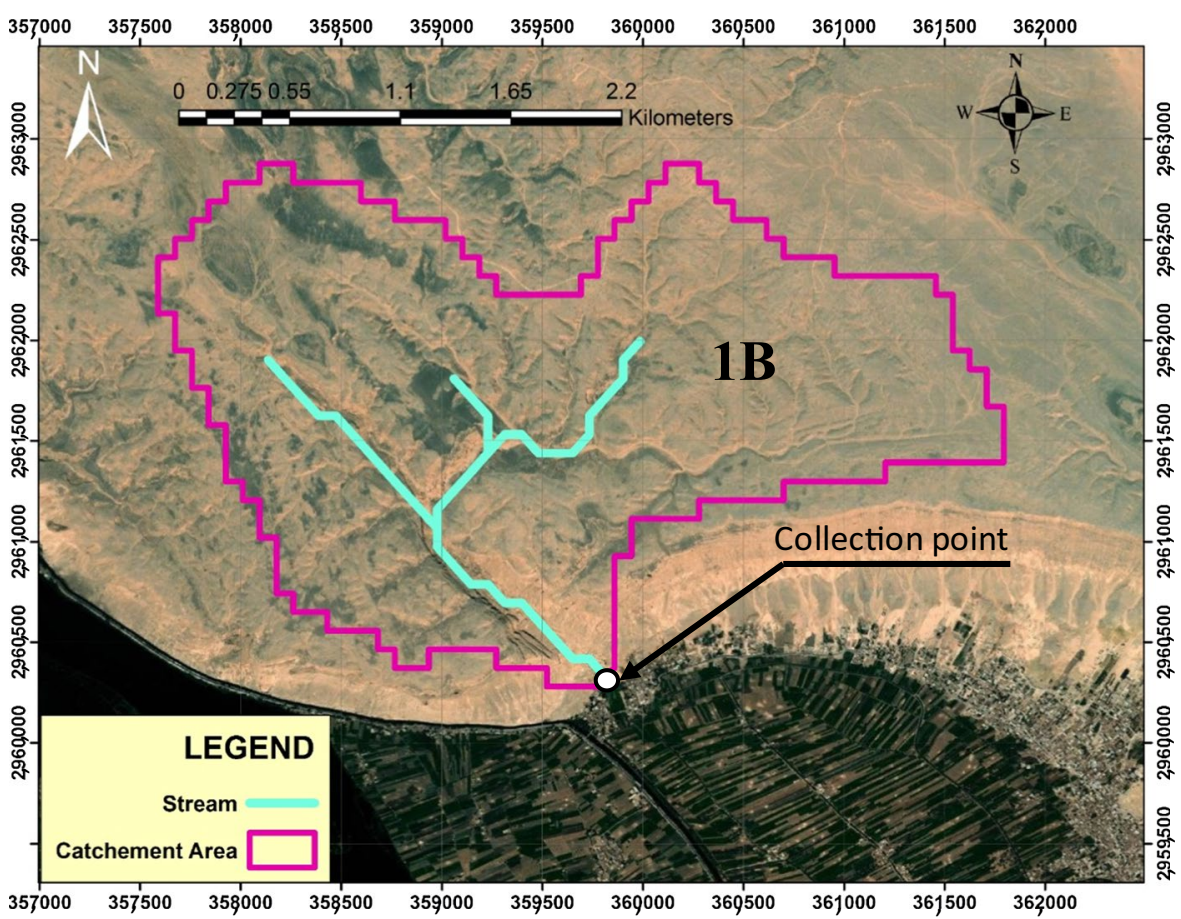

Fig. 5 The watershed and collection point for the study area

ranging from 10 to $100 \%$ based on the different datasets. In Fig. 6, the CMIP5 one member datasets with different RRs show a precipitation increase of up to $120 \mathrm{~mm} / \mathrm{year}$, which represents a $50 \%$ increase from the $83 \mathrm{~mm} /$ year estimated in a 1991 report (the highest in 40 years). Finally, according to the National Oceanic and Atmospheric Administration (NOAA), the world has witnessed a $0.8^{\circ} \mathrm{C}$ increase over the past 100 years (Bradford 2017). Figure 7 shows that temperature in the study area is expected to increase $3{ }^{\circ} \mathrm{C}$.

\subsection{Water quantity analysis}

The WMS software generated a delineated watershed with a $6.40 \mathrm{~km}^{2}$ area. Table 4 summarizes the morphological data of the basin. The short lag time is mainly due to the small area of the watershed and the high stream slope $(0.0576 \mathrm{~m} / \mathrm{m})$.

The total runoff volume estimated for Nagaa Mobarak Village is $275,000 \mathrm{~m}^{3}$ for the 100 -year return period considering the increase in precipitation due to climate change. Although this is not a significant amount of water, it poses a great risk because the short lag time (Abdulkareem et al. 2019) and low elevation of the village, which is located $25 \mathrm{~m}$ below the watershed at almost 51.5 MASL at the scale locations (Fig. 8).

A variety of solutions for flood management were identified that are commonly implemented, including storage ponds, routing channels, and dam construction (van Wesenbeeck et al. 2014). All these potential solutions are discussed in Sect. 4. It is worth noting that all are considered end-of-pipe solutions that focus on handling the generated floodwater and 

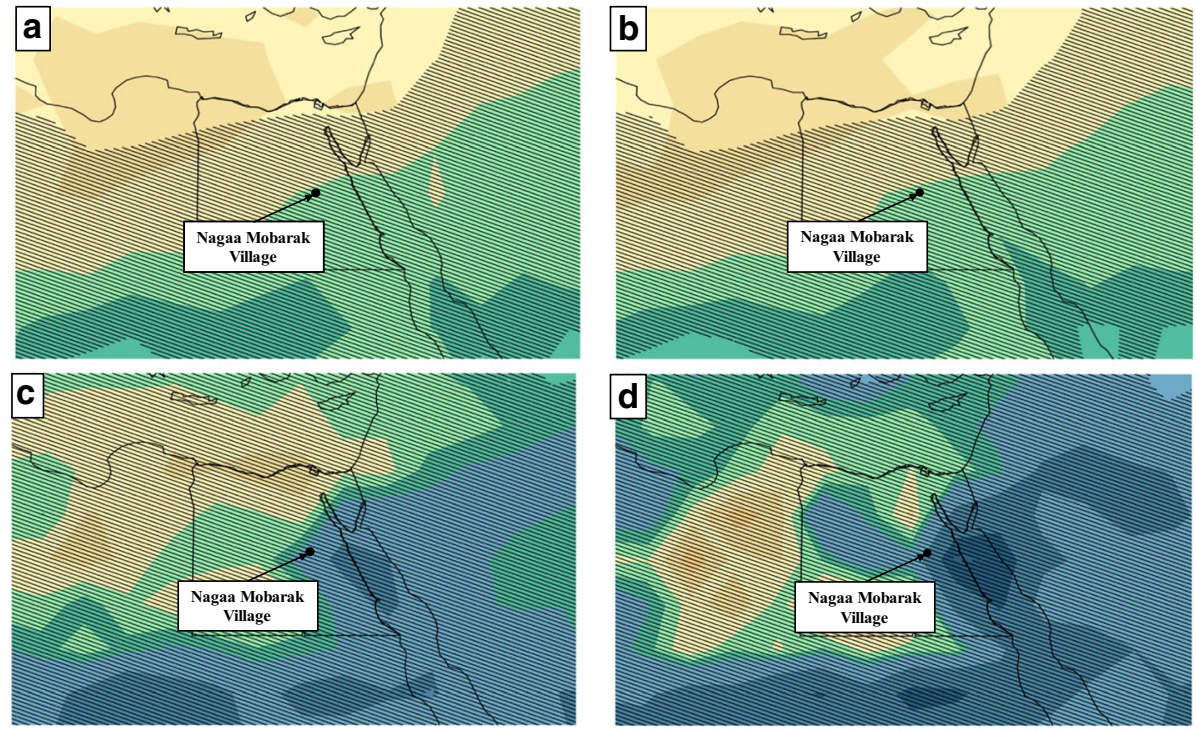

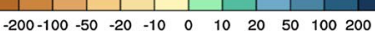

[\%]

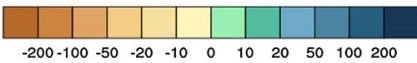

[\%]

Fig. 6 Expected change in future precipitation due to climate change, mean Representative Concentration Pathway (rcp45) relative precipitation 2081 - 2100 minus 1986 - 2005: a AR5 CMIP5, b CMIP5 ensemble, $\mathbf{c}$ CMIP5 one member when risk ratio (RR)>95p, and $\mathbf{d}$ CMIP5 one member when RR $>99 \mathrm{p}$ (Climate Explorer 2020)
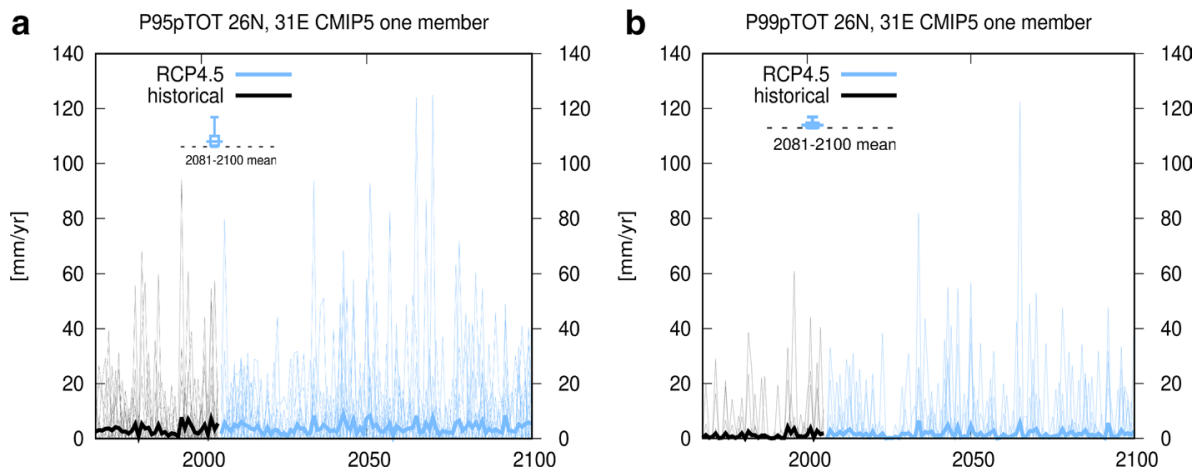

Fig. 7 Expected change in precipitation due to climate change CMIP5 one member when: $\mathbf{a}$ RR $>95 p$ and $\mathbf{b}$ RR > 99p (Climate Explorer 2020)

not on decreasing its amount or using it for other purposes, which is considered a major drawback (Marijnissen et al. 2020; Stefanakis 2019; van Wesenbeeck et al. 2014).

\subsection{Water quality analysis}

Table 5 shows water temperature and DO concentration changes due to climate change. Figure 9 shows the DO and temperature variation throughout the year considering climate 


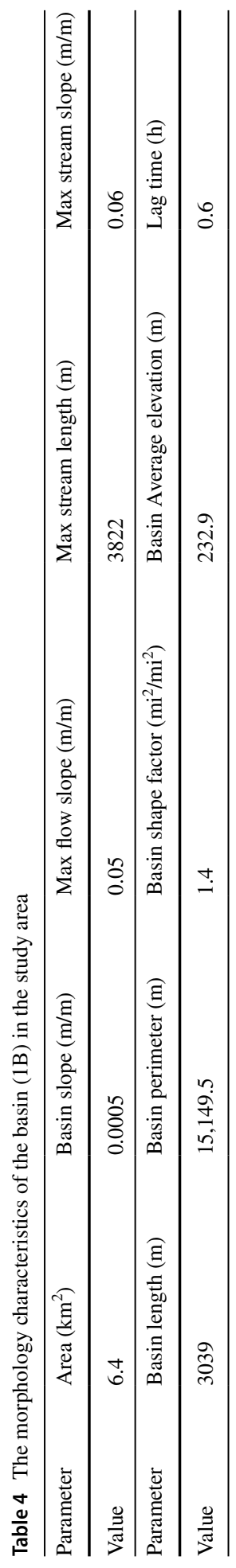



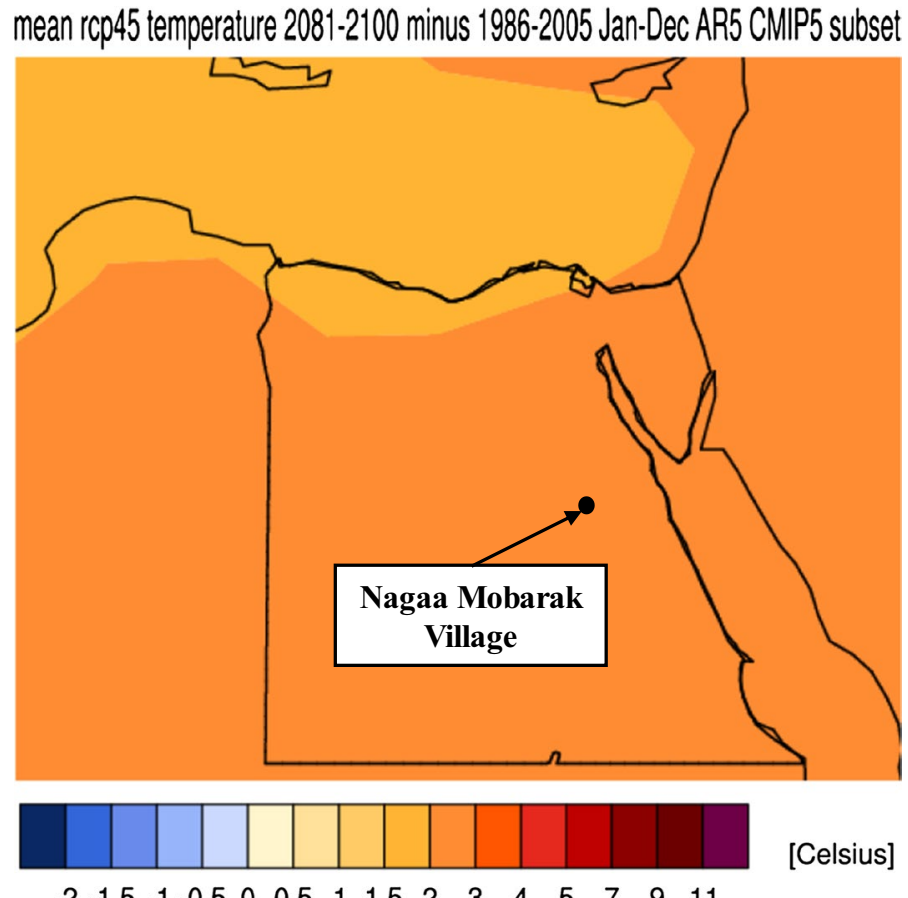

[Celsius]

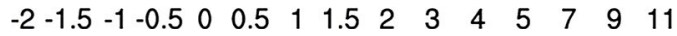

Fig. 8 Expected change in the future air temperature due to climate change (AR5 CMIP5) (Climate Explorer 2020)

Table 5 Expected temperature and DO content due to climate change

\begin{tabular}{llllll}
\hline Parameter & January & March & June & September & December \\
\hline Temp $\left({ }^{\circ} \mathrm{C}\right)$ & 17.13 & 23.87 & 34.1 & 34.97 & 19.04 \\
DO $(\mathrm{mg} / \mathrm{L})$ & 4.62 & 4.81 & 2.5 & 2.75 & 4.96 \\
WQI & 58 & 58 & 24 & 24 & 60 \\
\hline
\end{tabular}

change impacts. As shown in Table 5, temperature increased $1.8^{\circ} \mathrm{C}$ and DO concentration decreased $0.45 \mathrm{mg} / \mathrm{L}$ from the values shown in Table 2. Considering the DO concentration values shown in Table 2, this decrease in DO may not significantly impact water quality or harm aquatic organisms during winter months. However, DO concentration during the summer reaches a minimum of $2.5 \mathrm{mg} / \mathrm{L}$, which is lower than the recommended minimum DO for a level B protection of the health of aquatic organisms in fresh water bodies $(4 \mathrm{mg} / \mathrm{L})$ (Davis 1975). Level B protection implies that some organisms may exhibit symptoms of oxygen distress if the DO value remains at a set level for more than few hours (Davis 1975). Additionally, when the WQI values are used to compare water quality, the results are significant. As shown in Table 3, water quality in the NHC was found to be fair for the sampling campaigns in January (WQI=66) and March (WQI=66), whereas it was found to be bad in June and September (WQI=32 and 30, respectively) followed by a recovery in December when the water quality was fair again (WQI=68). The effect of climate change is significant in results from Table 5 because although water quality remains 


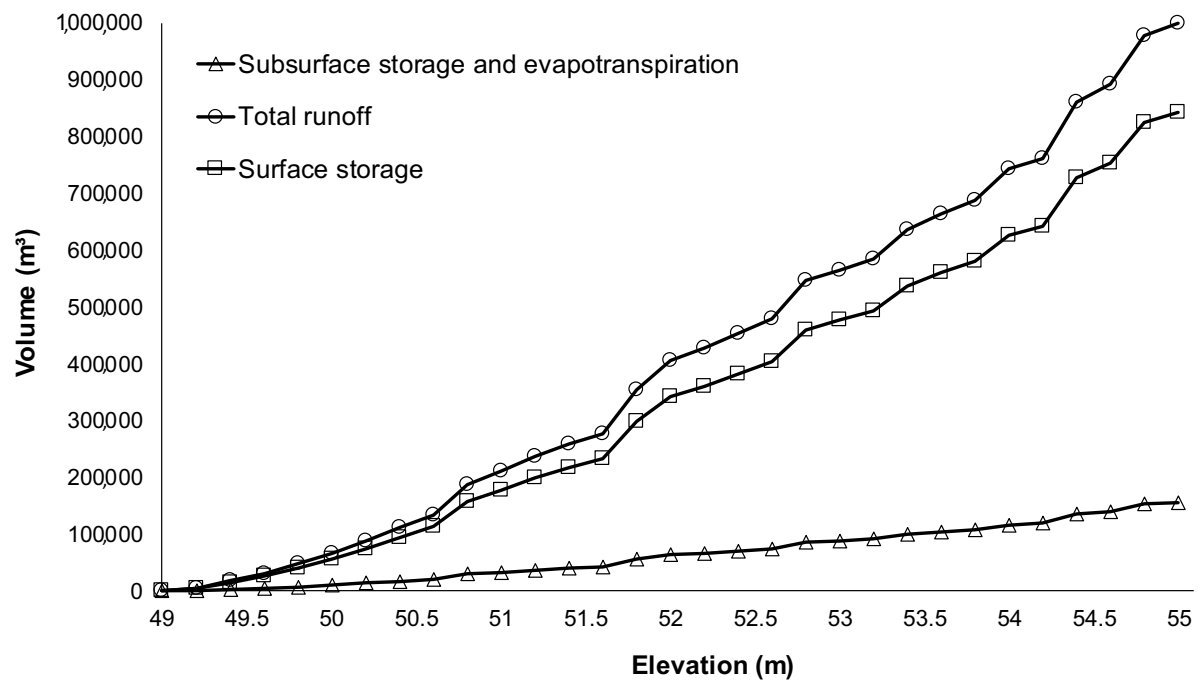

Fig. 9 Cumulative storage volume curve for the Nagaa Mobarak Village

fair for the January to March period (WQI=58 in both cases), it reaches the very bad category during June and September (WQI=2.5 and 2.75 for June and September, respectively) and does not recover until later in December $(\mathrm{WQI}=60)$. Clearly, the increase in water temperature significantly affects water quality and poses a threat to aquatic organisms, basin productivity, and the local economy (Fig. 10).

A sustainable approach is needed to design flood management alternatives that considers the three pillars of sustainability: people, profit, and the planet. The first two pillars

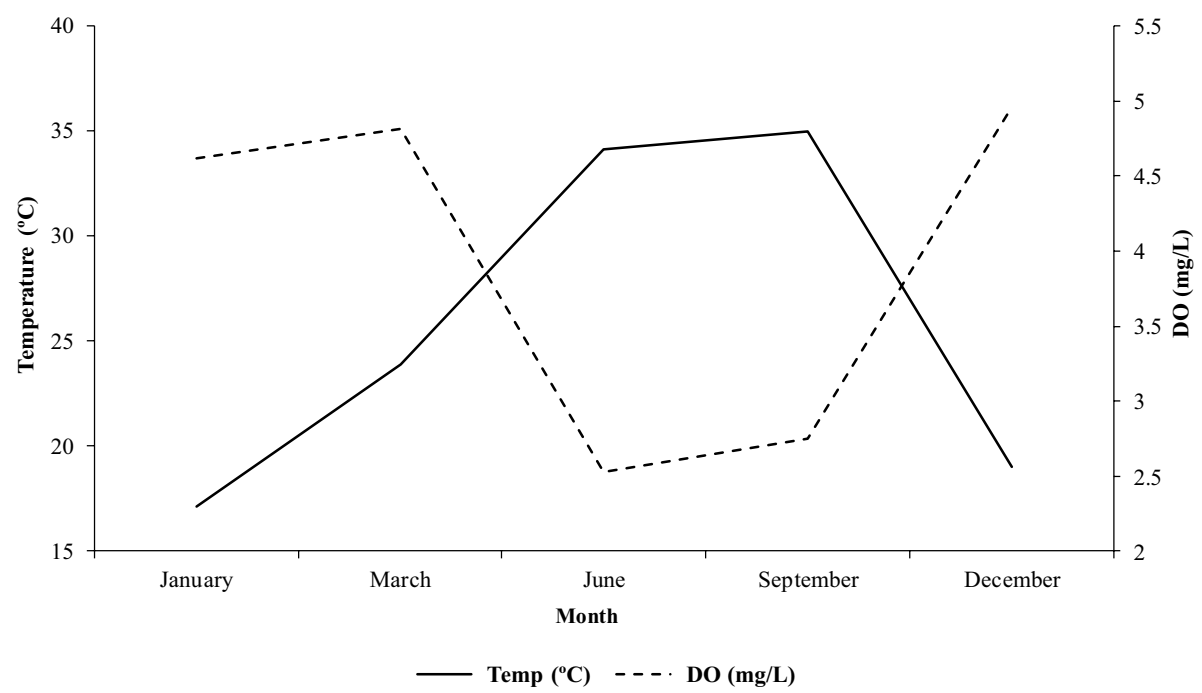

Fig. 10 DO and temperature variation given the impacts of climate change 


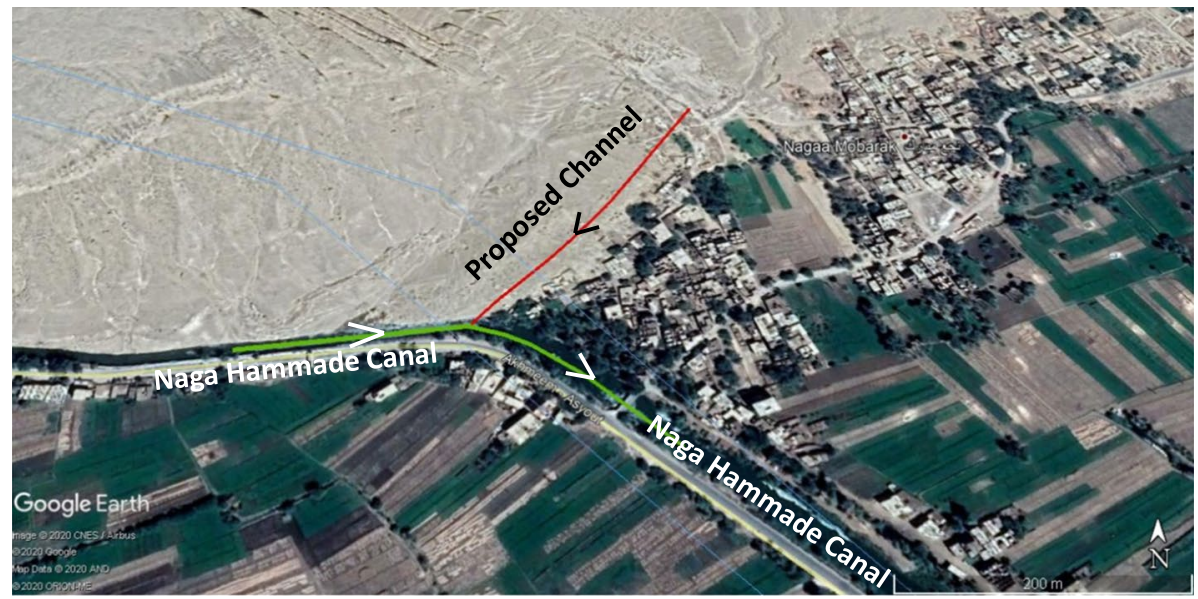

Fig. 11 The location of the proposed flood channel

were achieved by analyzing management alternatives to protect against the increased precipitation and associated damage to lives and properties. Only the third pillar still needs to be addressed. By using water quality to identify and analyze alternatives, the selection is bound to be more sustainable and resilient. This shall be further enhanced by integrating concepts of ecohydrology that focus on the interactions between biological systems and water bodies to ensure the prosperity of both (Fig. 11).

\section{Holistic, sustainable ecohydrological solutions}

\subsection{Traditional management alternatives}

The first proposed alternative is an artificial pond to collect the runoff at the collection point. The flood water collected in the artificial pond can be used for groundwater recharge (Morsy et al. 2018). However, a geological study found that Nagaa Mobarak Village is located on karstified carbon aquifer zone characterized by high salinity (Mosaad 2019). Consequently, using harvested rainfall for groundwater recharge is not feasible. Moreover, the pond would require a large area of land that might result in physical or economic displacement for local inhabitants in the area. Therefore, this alternative was not considered further (Ostad-Ali-Askari and Shayannejad, 2021).

The second proposed alternative was a dam that would act as a water barrier and store flood water. However, damming is a high-cost alternative for infrequent flash flood events. Damming is also considered a gray infrastructure solution, which is considered to be unsustainable and even increase climate change impacts (de Vriend et al. 2015; Peng et al. 2017). Therefore, this alternative was rejected based on economic and environmental points of view and was not considered further.

The third alternative was to construct a routing channel to transfer flood water directly to the NHC, which would protect the village from flash flood risks and conserve water by reusing flood water for irrigation (Mostafa and Peters 2015). This alternative was found to be cost-effective compared with the relatively high costs of dam and pond construction. 
Table 6 Properties of the proposed flood channel (FAO Training 2016; Abdelhaleem et al. 2016)

\begin{tabular}{llll}
\hline Parameter & Unit & $\begin{array}{l}\text { Proposed flood } \\
\text { channel }\end{array}$ & $\begin{array}{l}\text { Existing } \\
\text { infrastructure } \\
\text { (NHC) }\end{array}$ \\
\hline Depth & $\mathrm{m}$ & 1.0 & 4.0 \\
Bottom width & $\mathrm{m}$ & 2.0 & 8.0 \\
Side slope & - & $1: 1$ & $3: 2$ \\
Longitudinal slope & $\mathrm{cm} / \mathrm{km}$ & 1.5 & 2.03 \\
Flow rate & $\mathrm{m} 3 / \mathrm{sec}$ & 6.0 & 5.0 \\
\hline
\end{tabular}

Moreover, it introduces the possibility of reusing almost $275,000 \mathrm{~m}^{3}$ of flood water for irrigation. The most common crop in this region is sugarcane, which needs almost 18,000 $\mathrm{m}^{3}$ of water per hectare (Petheram and McMahon 2019). Conserving 275,000 $\mathrm{m}^{3}$ of flood water would help cultivate approximately 15 hectares of sugarcane. Sugar beet is also commonly cultivated in this region and requires almost $5950 \mathrm{~m}^{3}$ of water per hectare (Farag et al. 2017). In this case, approximately 46 hectares of sugar beets can be cultivated. Therefore, constructing a routing channel is considered the optimal traditional solution to manage the increase in water quantity from flash floods in light of climate change.

Table 6 shows the necessary characteristics of the proposed flood channel for the NHC generated using the EPA SWMM software to ensure the extra flow can be accommodated. The results show that the existing canal cross section will accommodate the flood water and the water depth in the canal will not exceed $2 \mathrm{~m}$, which is less than its design capacity $(2.5 \mathrm{~m})$.

\subsection{Non-traditional management alternatives}

Although traditional engineering solutions (gray infrastructure) have been commonly used in flood management, scientific evidence has been found that links increasing urbanization to a decrease in the provision and regulation of ecosystem services, including flood management (Peng et al. 2017). Therefore, the use of traditional solutions is considered unsustainable in light of the role played by ecosystem services in the environment (Bolund and Hunhammar 1999). The concept of NBS could be beneficial in planning for flood management measures that have the potential to improve water quality and protect lives and assets.

Wetlands, including constructed wetlands, are essential components for climate change adaptation and mitigation, as well as core elements for nature-based stormwater flood management (Erwin 2009; Malaviya and Singh 2012; Scholz and Lee 2005). Their advantages include achieving peak flow attenuation and water purification (Heal et al. 2006; Malaviya and Singh 2012; Wheater and Evans 2009) using natural elements with a net positive environmental impact. The concept of constructed wetlands has been widely described as a nature-based flood defense, and its efficacy has been proved at the landscape scale in several countries (de Vriend et al. 2015; Dou et al. 2017; McVittie et al. 2018). Generally, urban and agricultural stormwater runoff is characterized by a variety of pollutants from suspended solids to heavy metals depending on the land use (Kadlec 2009; Stefanakis 2019). Constructed wetlands have shown their potential to remove pollutants with varying efficiency (Fraley-McNeal et al. 2007). Therefore, including a constructed wetland along a section of the channel built to divert flow into the NHC would decrease runoff volume and peak time so that the capacity of the canal is not exceeded during a flood event 
and incoming stormwater is purified, which would improve stormwater quality and ensure NHC ecosystem health (Pirnazar et al. 2018). This was considered the optimal alternative from an ecohydrological perspective. Harrington (2019) estimated that the typical required hydraulic retention time (HRT) in a constructed wetland for stormwater management is five days and Blick et al. (2004) suggested an average depth of $3 \mathrm{~m}$ is required for treatment. For the purposes of this study case, in which the main wetland function is as a storage buffer and water purification is an auxiliary benefit, the proposed HRT is one day for half runoff flow $\left(137,500 \mathrm{~m}^{3}\right)$ and the required area equals $45,000 \mathrm{~m}^{2}$.

\subsection{Economic analysis of the ecohydrological solutions}

The main cost components for constructing the channel are the drilling and lining. The cost of different construction items was estimated based on quotations received from independent contractors working near to the study area (Sohag Governorate) in late 2020. The quotations included materials, transportation, and labor costs (Table 7). The operational and maintenance cost was assumed to be $5 \%$ of the capital costs for the routing channel (Houle et al. 2013; Petheram and McMahon 2019).

A cement lining with a thickness of $5 \mathrm{~cm}$ was selected based on the channel discharge and water depth and because of its long life, high durability, resistance to erosion, structure stability, and high permissible velocity. Table 8 illustrates the total cost estimate for channel construction operations. The total cost was $\$ 92,050$ including construction and operations and maintenance $(\mathrm{O} \& \mathrm{M})$ costs.

As for the constructed wetland, the main cost components are listed in Table 9 along with the cost per acre $\left(\sim 4047 \mathrm{~m}^{2}\right)$. It is worth noting that cost estimates were published from Texas, the United States of America (Sea Grant Texas 2012). The total construction of 11 acres would cost a minimum of $\$ 275,000$. However, costs could fluctuate from the

Table 7 Cost estimate per meter per process

Table 8 Total construction costs of the channel for the 100-year return period

\begin{tabular}{lc}
\hline Item & Cost $(\$)$ \\
\hline Drilling & 0.45 \\
Pitching & 19.23 \\
Cement & 58.00 \\
Reinforced concrete & 46.50 \\
\hline
\end{tabular}

\begin{tabular}{llll}
\hline Length $(\mathrm{m})$ & Area $\left(\mathrm{m}^{2}\right)$ & Perimeter $(\mathrm{m})$ & Lateral Area $\left(\mathrm{m}^{2}\right)$ \\
\hline Construction Cost & & & \\
313 & 3 & 4.83 & 4.83 \\
Drilling cost & $\$ 423$ & & \\
Cement lining cost & $\$ 87,200$ & \\
Total construction cost & $\$ 87,650$ & \\
O\&M costs & $\$ 4400$ & \\
Total cost & $\mathbf{\$ 9 2 , 0 5 0}$ & \\
\hline
\end{tabular}


Table 9 Cost estimate per acre per component (Sea Grant Texas 2012)

\begin{tabular}{ll}
\hline Item & Cost per Acre \\
\hline Earthworks and grading & $\$ 5000$ to 15,000 \\
Aquatic plants & $\$ 10,000$ to 20,000 \\
Spillway structure & $\$ 10,000$ to 15,000 \\
Total & $\$ 25,000$ to 50,000 \\
\hline
\end{tabular}

stated values and are expected to decrease significantly when relying on local supplies for the construction of the wetland.

\subsection{Limitations and application range of the proposed solution}

Although the proposed solution provides a plethora of benefits compared to traditional engineering flood management solutions, it still has its disadvantages. Wetlands, for example, require a large land footprint; they require more time for water treatment compared to traditional technologies and are associated with more uncertainties and vulnerabilities being dependent of natural resources to function (Andrikopoulou et al. 2021; Haddis et al. 2020; Oral et al. 2020; Rigotti et al. 2020). All of these requirements limit the large-scale implementation of nature-based and hybrid solutions despite their proved environmental superiority (Haddis et al. 2020; Oral et al. 2020). However, Egypt, and especially upper Egypt, is not in need of physical space. The area is mostly arid with groundwater only found at hundreds of meters below ground level. The wetland can be constructed at a vacant area at a distance from the village to be able to retain the water until its quality improves and provides enough buffer time to prevent the flooding of the canal. Finally, given the innovation of the solution, constant monitoring is imperative, especially in the early life of the project, in order to ensure the technology is working probably and further learn about the processes.

\section{Contribution to the SDGs}

According to Vörösmarty et al. (2018), investing in water security and flood management directly support to adoption of and public commitment to the SDGs. After assessing the impacts of our research using the UN's sustainable development goals, targets and indicators, our results found that through implementing the holistic sustainable approach to flood management, 10 out of the 17 goals will be impacted positively. Out of the 169 SDG targets and 232 unique indicators, the proposed approach to flood management contributes to 26 targets and 29 indicators, as presented in Table 10 below. The solution proposed in this study contributes, as would be expected, to two goals more than others, namely the sixth and eleventh goals. The solution supports to five indicators of the sixth goal on sustainable management of water; and six indicators of the eleventh goal on making cities safe, resilient and sustainable. The results of our SDG analysis are similar to what Andrikopoulou et al. (2021) found when applying their framework to identify the SDG contribution of fluvial nature-based solutions. 


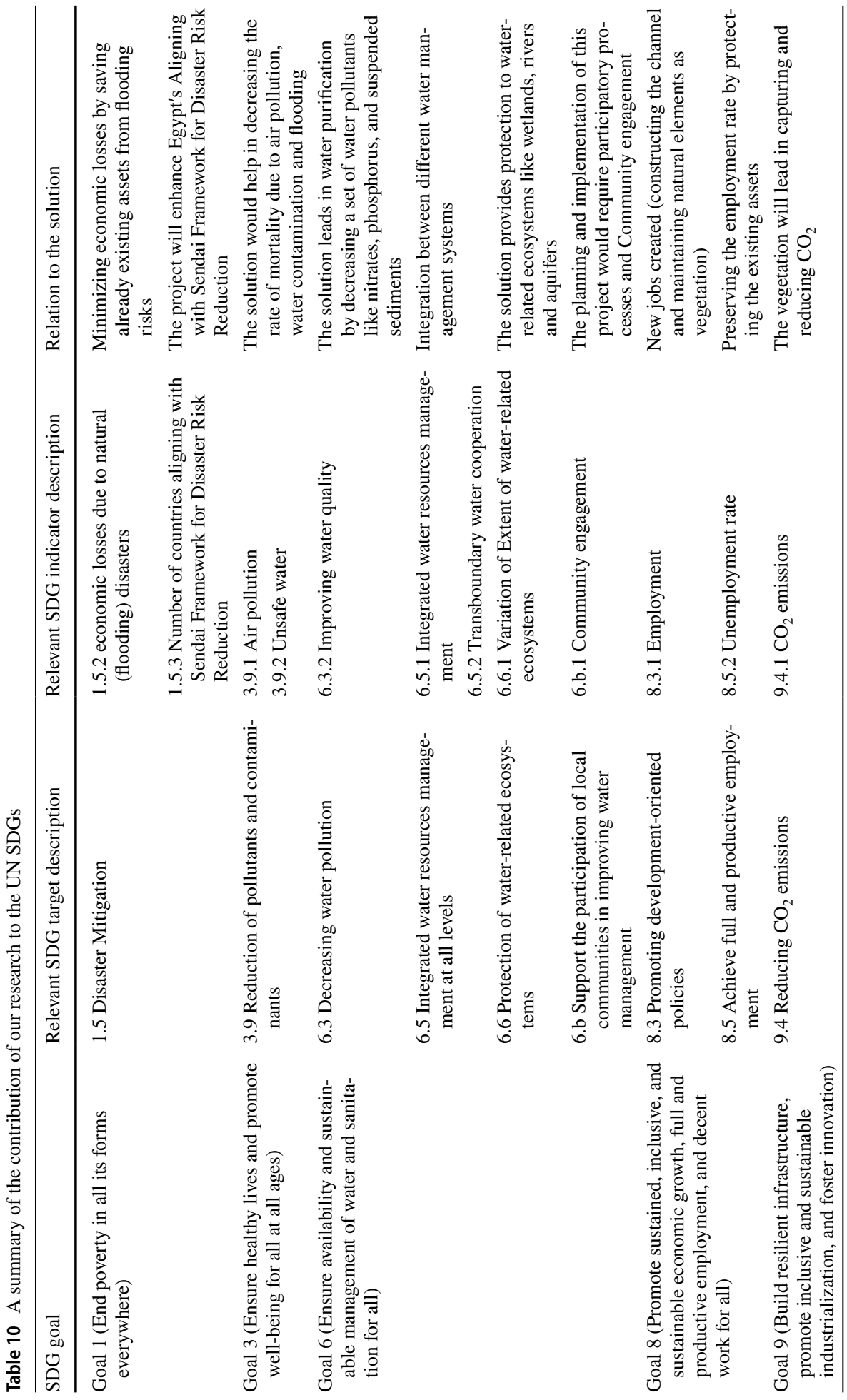




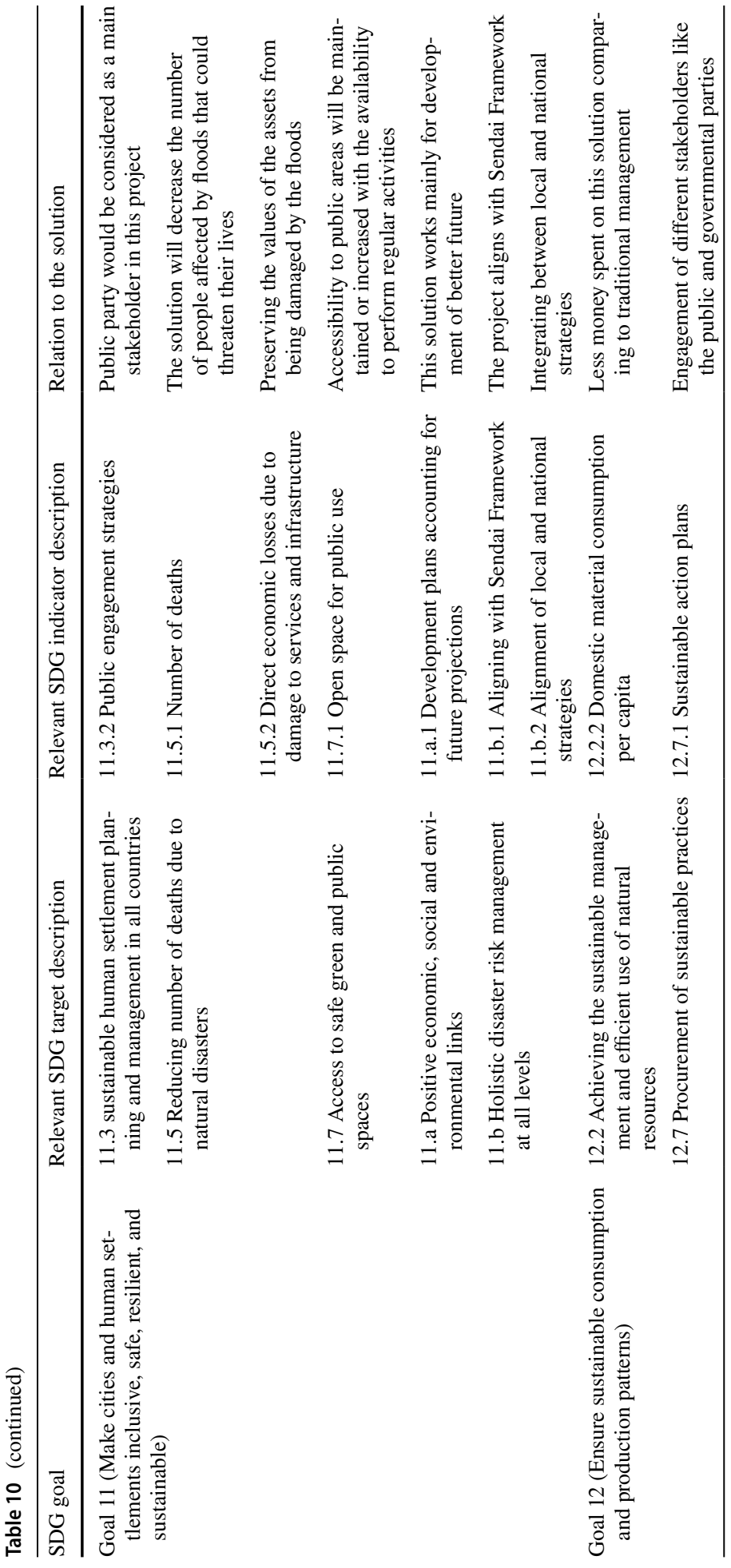




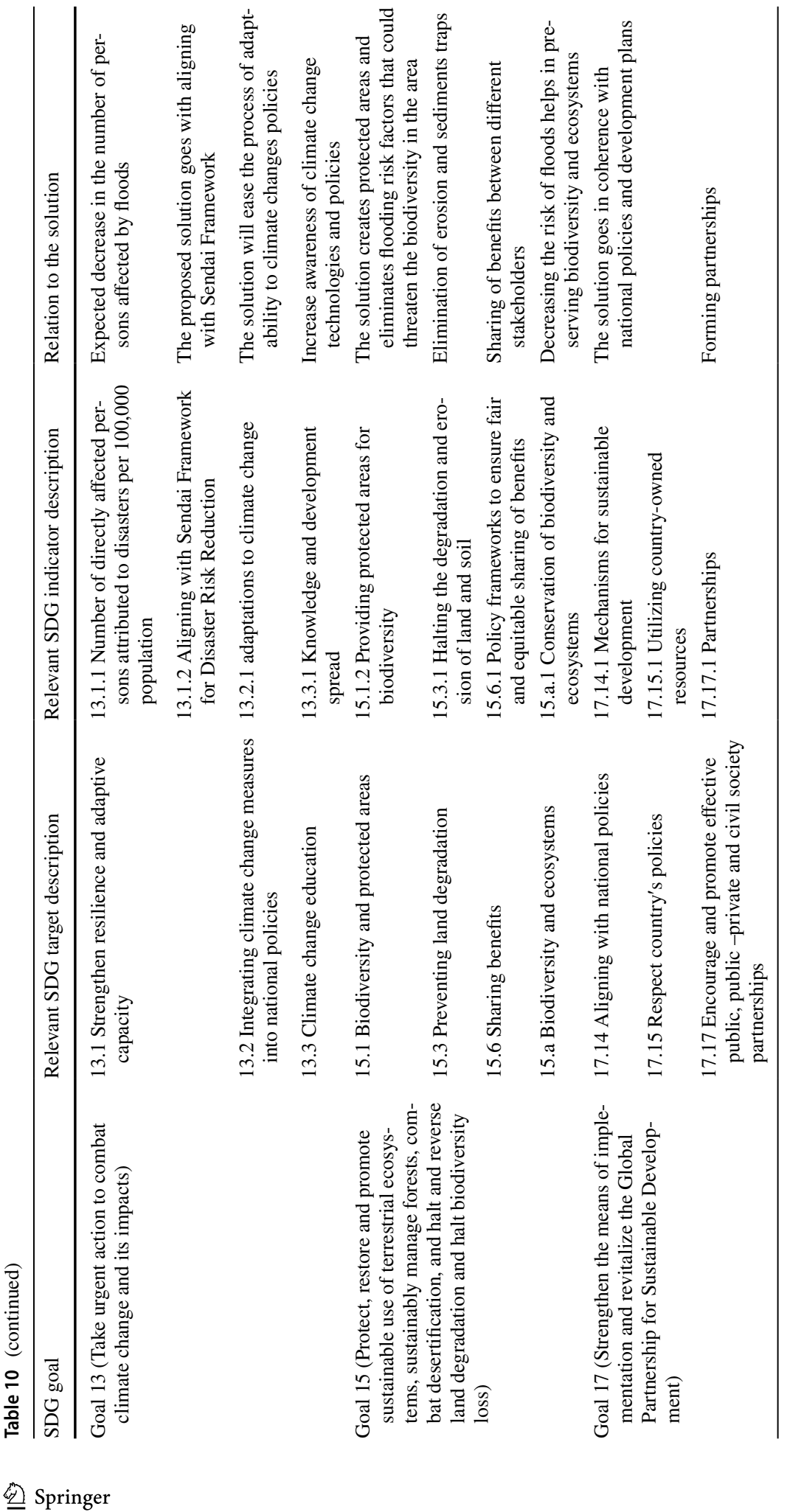




\section{Conclusions}

This paper offers a sustainable strategy for flash flood risk management in arid regions. The novelty of this study is based on addressing the dual effect of climate change on water quantity and quality. Moreover, it highlights the contribution of nature-based flood management methods to the SDGs. The village of Nagaa Mobarak in Souhag, Egypt, was taken as a case study given its historical precipitation record and vulnerability to flash floods. Due to climate change, the average precipitation in the study area is expected to increase by about $50 \%$, while the temperature in the area is expected to increase by $3^{\circ} \mathrm{C}$. Changes in these two factors lead to variations in water quantity and quality from regular conditions, and these variations need to be quantified and assessed in order to develop a holistic sustainable strategy for flood risk management. The study utilized modeling software to estimate the change in water quantity as a result of climate change and an ecohydrological approach covering to improve the expected water quality deterioration for watershed assessing both traditional and non-traditional management solutions. A comparative analysis was carried out for the proposed management alternatives in terms of efficiency and sustainability, followed by a cost estimate for the selected solution. The results of the study show that the optimal flood management measure is a hybrid one that employs both traditional and non-traditional solutions for flood management. A constructed wetland along a section of the constructed channel for diverting flow into the Nagaa Hammade Canal would serve to decrease the runoff volume and peak time so that the capacity of the Canal is not exceeded in a flood event as well as purify the incoming stormwater improving its quality and ensuring the health of the ecosystem within the canal. It is considered the most optimal of the three alternatives from an ecohydrological perspective. The proposed alternative supported the accomplishment of 29 indicators, 26 targets and 10 SDGs. The most indicators fell under goals 6 and 11 on sustainable water management and resilient cities, respectively.

This study highlights the importance of integrated approaches in managing water resources and their potential to supporting the implementation of the SDGs. The main problem with most developing countries is that they overlook the effect of climate change during flood management planning. It is imperative to understand the relationship between the climate change, water quantity and quality to ensure the resilience and sustainability of our cities. Therefore, future research is required to further explore the relationship between the three especially between climate change and water quality.

Acknowledgements This work was supported by Faculty of Engineering and Technology, Badr University in Cairo, Egypt, and Faculty of Engineering-Mataria, Helwan University. We would also like to thank Dr. Hossam Mahmoud, Department of Irrigation and Hydraulics, Cairo University, and Eng. Mohamed Farouk for their technical support. The authors also thank Ms. Nicole Damon (DRI) for her editorial review.

Author contributions All authors contributed to the study conception and design. Methodology, material preparation, data collection, analysis, and investigation were performed by [NH. R], [MK. M], [MM. A], [SA Z], [KM M]. The first draft of the manuscript was written by [NH. R] [MK. M], and all authors commented (reviewed and edited) on first draft of the manuscript. The second draft of the manuscript was written by $[\mathrm{NH} . \mathrm{R}]$ and $[\mathrm{HE}]$. The second draft was reviewed and edited by [KM M], [ER B], [MK. M] and [MM. A]. This manuscript was supervised by [MK. M], [MM. A], [SAZ], [KMM] and [ERB]. All authors read and approved the final manuscript.

Funding Open access funding provided by The Science, Technology. The author(s) received no financial support for the research, authorship, and/or publication of this article.

Data availability Not applicable. 
Code availability Not applicable.

\section{Declarations}

Conflict of interest The authors declare that they have no competing interests.

Ethical approval Not applicable.

Consent to participate Not applicable.

Consent to publish Not applicable.

Open Access This article is licensed under a Creative Commons Attribution 4.0 International License, which permits use, sharing, adaptation, distribution and reproduction in any medium or format, as long as you give appropriate credit to the original author(s) and the source, provide a link to the Creative Commons licence, and indicate if changes were made. The images or other third party material in this article are included in the article's Creative Commons licence, unless indicated otherwise in a credit line to the material. If material is not included in the article's Creative Commons licence and your intended use is not permitted by statutory regulation or exceeds the permitted use, you will need to obtain permission directly from the copyright holder. To view a copy of this licence, visit http://creativecommons.org/licenses/by/4.0/.

\section{References}

Abdeldayem OM, Eldaghar O, Mostafa MK, Habashy MM, Hassan AA, Hossam M, Morsy KM, Abdelrady A, Peters RW (2020) Mitigation plan and water harvesting of flashflood in arid rural communities using modelling approach: a case study in Afouna Village. Egypt Water 12:2565. https://doi.org/10. 3390/w12092565

Abdelhaleem FS, Amin AM, Ibraheem MM (2016) Updated regime equations for alluvial Egyptian canals. Alex Eng J 55(1):505-512. https://doi.org/10.1016/j.aej.2015.12.011

Abdelhafez AA, Metwalley SM, Abbas HH (2020) Irrigation: Water resources, types and common problems in Egypt. In: ES EO, Negm A (eds) Technological and Modern Irrigation Environment in Egypt;Springer: Cham, Switzerland; Springer Nature, Switzerland. pp 15-34. https://doi.org/10.1007/ 978-3-030-30375-4_2.

Abdelrady A, Sharma S, Sefelnasr A, El-Rawy M, Kennedy M (2020) Analysis of the performance of bank filtration for water supply in arid climates: case study in Egypt. Water 12:1816. https://doi.org/10. 3390/w12061816

Abd-El Monsef H (2018) A mitigation strategy for reducing flood risk to highways in arid regions: a case study of the El-Quseir-Qena highway in Egypt. J Flood Risk Manag 11:S158-S172. https://doi.org/ $10.1111 /$ jfr3.12190

Abdulkareem JH, Pradhan B, Sulaiman WNA, Jamil NR (2019) Development of lag time and time of concentration for a tropical complex catchment under the influence of long-term land use/land cover (LULC) changes. Arab J Geosci 12:101. https://doi.org/10.1007/s12517-019-4253-Z

Abdulrazzak M, Elfeki A, Kamis A, Kassab M, Alamri N, Chaabani A, Noor K (2019) Flash flood risk assessment in urban arid environment: case study of Taibah and Islamic universities' campuses, Medina, Kingdom of Saudi Arabia. Geomat Nat Hazards Risk 10:780-796. https://doi.org/10.1080/ 19475705.2018.1545705

Al-Ghwait K (2019) Learn about 100 Equipment, Dam and Industrial Lakes Sohag's Plans to Cope with Floods. Available online: www.elwatannews.com/, Accessed on 10 Nov 2020

Ali MA (2014) The Village of Nazlet Amara and Hajer Mushta Make a Distress Call 2014. Available online: https://www.almasryalyoum.com/, Accessed on 22 Dec 2020

Andrikopoulou T, Schielen RMJ, Spray CJ, Schipper CA, Blom A (2021) A Framework to evaluate the SDG contribution of fluvial nature-based solutions. Sus-Tainability 13(20):11320. https://doi.org/10. $3390 /$ su 132011320

Atwa M (2020) Flash flood management and harvesting via groundwater recharging in wadi systems: an integrative approach of remote sensing and direct current resistivity techniques. In: Negm AM (ed) Flash flood in Egypt. Spring, Switzerland, pp 107-119 
Awadallah AG, Saad H, Elmoustafa A, Hassan A (2016) Reliability assessment of water structures subject to data scarcity using the SCS-CN model. Hydrol Sci J 61:696-710. https://doi.org/10.1080/02626 667.2015.1027709

Awadallah AG, Magdy M, Helmy E, Rashed E (2017) Assessment of rainfall intensity equations enlisted in the egyptian code for designing potable water and sewage networks. Adv Meteorol. https://doi.org/10. $1155 / 2017 / 9496787$

Baldi M, Amin D, Al Zayed IS, Dalu G (2020) Climatology and dynamical evolution of extreme rainfall events in the Sinai Peninsula-Egypt. Sustainability 12:6186. https://doi.org/10.3390/su12156186

Blick SA, Kelly F, Skupien JJ (2004) NJ Stormwater Best Management Practices Manual. New Jersey Department of Environmental Protection

Bolund P, Hunhammar S (1999) Ecosystem services in urban areas. Ecol Econ 29(2):293-301. https://doi. org/10.1016/S0921-8009(99)00013-0

Bradford A (2017) Effects of Global Warming 2017. Available online: https://www.livescience.com/37057global-warming-effects.html\#: :text=One $\% 20$ of $\% 20$ the $\% 20$ most $\% 20$ immediate, and $\% 20$ Atmosphe ric\%20Administration\%20(NOAA), Accessed on 10 Jan 2021

Climate Explorer (2020) World Meteorological Organization. Available online: https://climexp.knmi.nl/ start.cgi, Accessed on 10 Jan 2021

Cohen-Shacham E, Walters G, Janzen C, Maginnis S (Eds.) (2016) Nature-based solutions to address global societal challenges. IUCN International Union for Conservation of Nature. https://doi.org/10.2305/ IUCN.CH.2016.13.en

Davis JC (1975) Minimal dissolved oxygen requirements of aquatic life with emphasis on Canadian species: a review. J Fish Res Board Can 32(12):2295-2332. https://doi.org/10.1139/f75-268

de Vriend HJ, van Koningsveld M, Aarninkhof SGJ, de Vries MB, Baptist MJ (2015) Sustainable hydraulic engineering through building with nature. J Hydro-Environ Res 9(2):159-171. https://doi.org/10. 1016/j.jher.2014.06.004

Destro E, Amponsah W, Nikolopoulos EI, Marchi L, Marra F, Zoccatelli D, Borga M (2018) Coupled prediction of flash flood response and debris flow occurrence: application on an alpine extreme flood event. J Hydrol 558:225-237. https://doi.org/10.1016/j.jhydrol.2018.01.021

Di Baldassarre G, Kreibich H, Vorogushyn S, Aerts J, Arnbjerg-Nielsen K, Barendrecht M, Bates P, Borga M, Botzen W, Bubeck P et al (2018) Hess opinions: an interdisciplinary research agenda to explore the unintended consequences of structural flood protection. Hydrol Earth Syst Sci 22:5629-5637. https://doi.org/10.5194/hess-22-5629-2018

Dou T, Troesch S, Petitjean A, Gábor PT, Esser D (2017) Wastewater and rainwater management in urban areas: a role for constructed wetlands. Procedia Environ Sci 37:535-541. https://doi.org/10.1016/j. proenv.2017.03.036

Durga Rao KHV, Bhaumik MK (2003) Spatial expert support system in selecting suitable sites for water harvesting structures-A case study of song watershed, Uttaranchal. India Geocarto Int 18:43-50. https://doi.org/10.1080/10106040308542288

Dweependra NK (2008) A study of basin response using HEC-HMS and subzone reports of CWC 2008. https://doi.org/10.13140/2.1.1470.2724

El-Afandi G, Morsy M (2020) Developing an early warning system for flash flood in Egypt: Case study Sinai Peninsula. In: Negm AM (ed) Flash Floods in Egypt. Springer: Berlin/Heidelberg, Germany, Accessed on 24 Aug 2020

El-Magd SAA et al (2020) Multi-criteria decision-making for the analysis of flash floods: a case study of Awlad Toq-Sherq, Southeast Sohag, Egypt. J Afr Earth Sci 162:103709. https://doi.org/10.1016/j. jafrearsci.2019.103709

El-Sayed E (2018) Development of synthetic rainfall distribution curves for Sinai area. Ain Shams Eng J 9:1949-1957. https://doi.org/10.1016/j.asej.2017.01.010

El-Sheekh M (2009) River Nile Pollutants and Their Effect on Life Forms and Water Quality 395-405. https://doi.org/10.1007/978-1-4020-9726-3_19

Erwin KL (2009) Wetlands and global climate change: The role of wetland restoration in a changing world. Wetlands Ecol Manag 17(1):71-84. https://doi.org/10.1007/s11273-008-9119-1

European Commission (2015) Towards an EU research and innovation policy agenda for nature-based solutions \& re-naturing cities: Final report of the Horizon 2020 expert group on Nature based solutions and re naturing cities. Publications Office. https://doi.org/10.2777/765301

Fatahi Nafchi R, Yaghoobi P, Reaisi Vanani H, Ostad-Ali-Askari K, Nouri J, Maghsoudlou B (2021) Ecohydrologic stability zonation of dams and power plants using the combined models of SMCE and CEQUALW2. Appl Water Sci 11(7):109. https://doi.org/10.1007/s13201-021-01427-z

Fathy I, Abd-Elhamid HF, Negm AM (2019) Prediction and mitigation of flash floods in Egypt. In: Negm AM (ed) Flash floods in Egypt. Springer, Berlin/Heidelberg, Germany 
Farag AA, Abdrabbo MAA, Taher MSK, Farag HA (2017) Comparative Study of the Production of Sugar Crops Under Limited Water. In Proceeding of the 5th international conference for Agricultural and Bioengineering, Egypt, 26-27 September 2017

FAO Training (2016) Water Transport Structures 2016. Available online: http://www.fao.org/tempref/FI/ CDrom/FAO_Training/FAO_Training/General/x6708e/x6708e08.htm, Accessed on 22 Nov 2020

Fraley-McNeal L, Schueler T, Winer R (2007) National Pollutant Removal Performance Database- Version 3. Center for Watershed Protection

Freni G, Liuzzo L (2019) Effectiveness of rainwater harvesting systems for flood reduction in residential urban areas. Water 11:1389. https://doi.org/10.3390/w11071389

Global Weather Data for SWAT 1979-2014. Available online: https://globalweather.tamu.edu/, Accessed on 30 Jan 2020

Golian M, Katibeh H, Singh VP, Ostad-Ali-Askari K, Rostami HT (2020) Pre-diction of tunnelling impact on flow rates of adjacent extraction water wells. Q J Eng GeolHydrogeol 53(2):236-251. https://doi.org/10.1144/qjegh2019-055

Haddis A, van der Bruggen B, Smets I (2020) Constructed wetlands as nature based solutions in removing organic pollutants from wastewater under irregular flow condi-tions in a tropical climate. Ecohydrol Hydrobiol 20(1):38-47. https://doi.org/10.1016/J.ECOHYD.2019.03.001

Hafshejani SS, Shayannejad M, Broujeni HS, Zarraty AR, Soltani B, Esfahani EM, Hamedani MH, Eslamian S, Askari KOA (2019) Determination of the height of the vertical filter for heterogeneous Earth dams with vertical clay core. Int J Hydrol Sci Technol 9(3):221. https://doi.org/10.1504/ IJHST.2019.102315

Harrington S (2019) Calculating the hydraulic efficiency of a constructed wetland. Available online at: https://watersource.awa.asn.au/environment/built-environment/calculating-the-hydraulic-effic iency-of-a-constructed-wetland/, Accessed on 10 Nov 2020

Heal KV, Hepburn DA, Lunn RJ (2006) Sediment management in sustainable urban drainage system ponds. Water Sci Technol 53(10):219-227. https://doi.org/10.2166/wst.2006.315

Hettiarachchi S, Wasko C, Sharma A (2018) Increase in flood risk resulting from climate change in a developed urban watershed-the role of storm temporal patterns. Hydrol Earth Syst Sci 22:20412056. https://doi.org/10.5194/hess-22-2041-2018

Houle JJ, Roseen RM, Ballestero TP, Puls TA, Sherrard J (2013) Comparison of maintenance cost, labor demands, and system performance for LID and conventional stormwater management. J Environ Eng 139:932-938

Hydrologic Engineering Center. Hydrologic Modeling System (HEC-HMS) Application Guide: Version 3.1.0, 2006. Institute for Water Resources. Available online: www.hec.usace.army.mil/software/ hec-hms/documentation/HEC-HMS_Users_Manual_3.1.0.pdf, Accessed on 10 Nov 2020

ISRIC (2020) World Soil Information SoilGrids-Global Gridded Soil Information. Available online: https://www.isric.org/explore/soilgrids, Accessed on 16 Nov 2020

Jeppesen E, Kronvang B, Meerhoff M, Søndergaard M, Hansen K, Andersen H, Lauridsen T, Liboriussen L, Beklioglu M, Özen A, Olesen J (2009) Climate change effects on runoff, catchment phosphorus loading and lake ecological state, and potential adaptations. J Environ Qual 38:1930-1941

Kadlec RH (2009) Wastewater treatment at the Houghton Lake wetland: hydrology and water quality. Ecol Eng 35(9):1287-1311. https://doi.org/10.1016/j.ecoleng.2008.10.001

Khalid R (2019) After the 2016 Torrent Disaster, Sohag Prepares for Torrents with Industrial Dams and Lakes. Implementing Support Plans with the Necessary Equipment and Capabilities during the Crisis 2019. Available online: www.elbalad.news/, Accessed on 24 Dec 2020

Kim RH, Lee S, Kim YM, Lee JH, Kim SK, Kim SG (2005) Pollutants in rainwater runoff in Korea: their impacts on rainwater utilization. Environ Technol 26:411-420. https://doi.org/10.1080/09593 332608618546

Kumar A, Gupta AK, Bhambri R, Verma A, Tiwari SK, Asthana AKL (2018) Assessment and review of hydrometeorological aspects for cloudburst and flash flood events in the third pole region (Indian Himalaya). Polar Sci 18:5-20. https://doi.org/10.1016/j.polar.2018.08.004

Kumar M, Sharif M, Ahmed S (2017) Flood risk management strategies for national capital territory of Delhi, India. Ish J Hydraul Eng 25:248-259. https://doi.org/10.1080/09715010.2017.1408434

Kundzewicz ZW, Su B, Wang Y, Xia J, Huang J, Jiang T (2019) Flood risk and its reduction in China. Adv Water Resour 130:37-45. https://doi.org/10.1016/j.advwatres.2019.05.020

Laity JJ (2008) Deserts and desert environments. John Wiley \& Sons, New York, NY, USA, p 360

Lyu H-M, Shen S-L, Yang J, Yin Z-Y (2019a) Inundation analysis of metro sys-tems with the storm water management model incorporated into a geographical infor-mation system: a case study in Shanghai. Hydrol Earth Syst Sci 23(10):4293-4307. https://doi.org/10.5194/hess-23-4293-2019 
Lyu H-M, Shen S-L, Zhou A, Yang J (2019b) Perspectives for flood risk assessment and management for mega-city metro system. Tunn Undergr Space Technol 84:31-44. https://doi.org/10.1016/j.tust.2018. 10.019

Lyu H-M, Shen S-L, Zhou A-N, Zhou W-H (2019c) Flood risk assessment of met-ro systems in a subsiding environment using the interval FAHP-FCA approach. Sustain Cities Soc 50:101682. https://doi.org/ 10.1016/j.scs.2019.101682

Lyu H-M, Sun W-J, Shen S-L, Arulrajah A (2018) Flood risk assessment in metro systems of mega-cities using a GIS-based modeling approach. Science Total Environ 626:1012-1025. https://doi.org/10. 1016/j.scitotenv.2018.01.138

Lyu H-M, Zhou W-H, Shen S-L, Zhou A-N (2020) Inundation risk assessment of metro system using AHP and TFN-AHP in Shenzhen. Sustain Cities Soc 56:102103. https://doi.org/10.1016/j.scs.2020.102103

Mackay D, Fleming G (1969) Correlation of dissolved oxygen levels, freshwater flows and temperatures in a polluted estuary. Water Res 3:121-128. https://doi.org/10.1016/0043-1354(69)90030-X

Malaviya P, Singh A (2012) Constructed wetlands for management of urban stormwater runoff. Crit Rev Environ Sci Technol 42(20):2153-2214. https://doi.org/10.1080/10643389.2011.574107

Marijnissen R, Esselink P, Kok M, Kroeze C, van Loon-Steensma JM (2020) How natural processes contribute to flood protection-A sustainable adaptation scheme for a wide green dike. Sci Total Environ 739:139698. https://doi.org/10.1016/j.scitotenv.2020.139698

Mashaly J, Ghoneim E (2018) Flash flood hazard using optical, radar, and stereo-pair derived dem: Eastern desert. Egypt Remote Sens 10:1204. https://doi.org/10.3390/rs10081204

Matute WG, Mostafa MK, Attoh D, Chawla RC, Peters RW (2016) Sustainable urban water management. Sustain Water Manag Technol. https://doi.org/10.1201/9781315373850

McVittie A, Cole L, Wreford A, Sgobbi A, Yordi B (2018) Ecosystem-based solutions for disaster risk reduction: lessons from European applications of ecosystem-based adaptation measures. Int J Disaster Risk Reduct 32:42-54. https://doi.org/10.1016/j.ijdrr.2017.12.014

Maqbool (2019) Learn about 22 Natural and Artificial Outlets of Seoul in Sohag Governorate 2019. Available online at: www.youm7.com/story/2019/9/17, Accessed on 15 Nov 2020

Mangala OS, Toppo P, Ghoshal S (2016) Study of infiltration capacity of different soils. Int J Trend Res Dev 3(2):388-390

Morrill JC, Bales RC, Conklin MH (2005) Estimating stream temperature from air temperature: implications for future water quality. J Environ Eng 131(1):139-146. https://doi.org/10.1061/(ASCE)07339372(2005)131:1(139)

Morsy KM, Abdelatif G, Mostafa MK (2021) Comprehensive assessment for the potential environmental impacts of the grand Ethiopian Renaissance Dam on the Downstream Countries: Itaipu Dam in the Rearview Mirror. Air Soil Water Res 14:1-12. https://doi.org/10.1177/11786221211041964

Morsy KM, Mishra AK, Galal MM (2020a) Water quality assessment of the Nile Delta Lagoons. Air Soil Water Res 13:117862212096307. https://doi.org/10.1177/1178622120963072

Morsy K, Morsy A, Morsy M, Thakeb H (2017) Eutrophication of aquatic ecosystems: a viewpoint on the environmental impact of climate change. J Environ Sci Eng B 6(10):506-514. https://doi.org/10. $17265 / 2162-5263 / 2017.10 .002$

Morsy KM, Morsy AM, Hassan AE (2018) Groundwater sustainability: opportunity out of threat. Groundw Sustain Dev 7:277-285. https://doi.org/10.1016/j.gsd.2018.06.010

Moss B, Kosten S, Meerhoff M, Battarbee R, Jeppesen E, Mazzeo N, Havens K, Lacerot G, Liu Z, De Meester L, Paerl H, Scheffer M (2011) Allied attack: climate change and eutrophication. Inland Waters 1:101-105

Morsy KM, Mostafa MK, Abdalla KZ, Galal MM (2020b) Life cycle assessment of upgrading primary wastewater treatment plants to secondary treatment including a circular economy approach. Air Soil Water Res 13:1-13. https://doi.org/10.1177/1178622120935857

Mosaad S (2019) Integration of geochemical data to assess the groundwater quality in a carbonate aquifer in the southeast of Beni-Suef city, Egypt. J Afr Earth Sci 158:103558. https://doi.org/10.1016/j.jafre arsci.2019.103558

Mostafa MK, Ighere JO, Chawla RC, Peters RW (2016) Groundwater protection and remediation. Sustain Water Technol. https://doi.org/10.1201/9781315373867

Mostafa MK, Peters RW (2015) (2481) Simulating the Effect of Changing the Effluent Path of OmarBek Drain in the Damietta Branch Water Quality I AIChE. In: AIChE annual meeting proceedings (November 8-13). Salt Lake City, UT

National Aeronautics and Space Administration (NASA) (2020) Total Rainfall. Available online: https:// earthobservatory.nasa.gov/global-maps/TRMM_3B43M, Accessed on 30 Jan 2020

NRI (2008) Nile Water Quality Status During 2007. Nile Research Institute. National Water Research Center (NWRC) Ministry of Water Resources and Irrigation. Feb. 2008 
Nafchi RF, Samadi-Boroujeni H, Vanani HR, Ostad-Ali-Askari K, Brojeni MK (2021) Laboratory investigation on erosion threshold shear stress of cohesive sediment in Karkheh Dam. Environ Earth Sci 80(19):681. https://doi.org/10.1007/s12665-021-09984-X

Oral HV, Carvalho P, Gajewska M, Ursino N, Masi F, Hullebusch EDV, Kazak JK, Exposito A, Cipolletta G, Andersen TR, Finger DC, Zimmermann M (2020) A review of nature-based solutions for urban water management in European circular cities: a critical assessment based on case studies and literature. Blue-Green Syst 2(1):112-136. https://doi.org/10.2166/bgs.2020.932

Omar MEDM, Moussa AMA, Hinkelmann R (2021) Impacts of climate change on water quantity, water salinity, food security, and socioeconomy in Egypt. Water Sci Eng 14(1):17-27. https://doi.org/10. 1016/j.wse.2020.08.001

Ostad-Ali-Askari K, Ghorbanizadeh Kharazi H, Shayannejad M, Zareian MJ (2019) Effect of management strategies on reducing negative impacts of climate change on water resources of the IsfahanBorkhar aquifer using MODFLOW. River Res Appl 35(6):611-631. https://doi.org/10.1002/rra. 3463

Ostad-Ali-Askari K, Hossein, Ghorbanizadeh Kharazi M, Shayannejad M, Zareian MJ (2020) Effect of Climate Change on Precipitation Patterns in an Arid Region Using GCM Models: Case Study of Isfahan-Borkhar Plain. Nat Hazards Rev 21(2):04020006. https://doi.org/10.1061/(ASCE)NH. 1527-6996.0000367

Ostad-Ali-Askari K, Shayannejad M (2021) Quantity and quality modelling of groundwater to manage water resources in Isfahan-Borkhar Aquifer. Environ Devel Sustainability 23(11):15943-15959. https://doi.org/10.1007/s10668-021-01323-1

Orlob GT, Meyer GK, Somlyódy L, Jurak D, Szesztay K (1996) Impacts of Climate Change on Water Quality. In: Kaczmarek Z, Strzepek KM, Somlyódy L, Priazhinskaya V (Eds), Water Resources Management in the Face of Climatic/Hydrologic Uncertainties. Springer, Netherlands. (Vol 18, pp 70-105), https://doi.org/10.1007/978-94-009-0207-7_4

Parvin GA, Shimi AC, Shaw R, Biswas C (2016) Flood in a changing climate: the impact on livelihood and how the rural poor cope in Bangladesh. Climate 4:60. https://doi.org/10.3390/cli4040060

Peng J, Tian L, Liu Y, Zhao M, Hu Y, Wu J (2017) Ecosystem services response to urbanization in metropolitan areas: Thresholds identification. Sci Total Environ 607-608:706-714. https://doi.org/10. 1016/j.scitotenv.2017.06.218

Petheram C, McMahon TA (2019) Dams, dam costs and damnable cost overruns. J Hydrol X 3:100026. https://doi.org/10.1016/j.hydroa.2019.100026

Pirnazar M, Hasheminasab H, Karimi AZ, Askari KOA, Ghasemi Z, Hamedani MH, Esfahani EM, Eslamian S (2018) The evaluation of the usage of the fuzzy algorithms in increasing the accuracy of the extracted land use maps. Int J Global Environ Issues 17(4):307. https://doi.org/10.1504/IJGEN VI.2018.095063

Prama M, Omran A, Schröder D, Abouelmagd A (2020) Vulnerability assessment of flash floods in Wadi Dahab Basin Egypt. Environ Earth Sci 79:114. https://doi.org/10.1007/s12665-020-8860-5

Project VT (2018) VTP 2018. Available online: http://vterrain.org/Doc/VTBuilder/overview.html, Accessed on 5 Oct 2020

Rajasekhar M, Gadhiraju SR, Kadam A, Bhagat V (2020) Identification of groundwater recharge-based potential rainwater harvesting sites for sustainable development of a semiarid region of southern India using geospatial, AHP, and SCS-CN approach. Arab J Geosci 13:24. https://doi.org/10.1007/ s12517-019-4996-6

Ramakrishnan D, Bandyopadhyay A, Kusuma KN (2009) SCS-CN and GIS-based approach for identifying potential water harvesting sites in the Kali Watershed, Mahi River Basin, India. J Earth Syst Sci 118:355-368. https://doi.org/10.1007/s12040-009-0034-5

Rigotti JA, Ribeiro Rodrigues L, Postal Pasqualini J (2020) Nature-based solutions for managing the urban surface runoff: an application of a constructed floating wet-land. Limnetica 39(1):441-454. https://doi.org/10.23818/limn.39.28

Romero R, Emanuel K (2017) Climate change and hurricane-like extratropical cyclones: projections for north Atlantic polar lows and medicanes based on CMIP5 models. J Clim 30:279-299. https://doi. org/10.1175/jcli-d-16-0255.1

Sanchez E, Colmenajero MF, Civente J, Rubio A, Garcia MG, Travieso L, Borja R (2007) Use of the water quality index and dissolved oxygen deficit as simple indicators of watersheds pollution. Ecol Ind 7:315-328. https://doi.org/10.1016/j.ecolind.2006.02.005

Scheres S (2019) Enhancing the ecological value of sea dikes. Water 11(8):1617. https://doi.org/10. $3390 /$ w1 1081617

Scholz M, Lee B (2005) Constructed wetlands: a review. Int J Environ Stud 62(4):421-447. https://doi. org/10.1080/00207230500119783 
Sea Grant Texas (2012) Stormwater Wetlands for the Texas Gulf Coast. https://cdn-ext.agnet.tamu.edu/wpcontent/uploads/2019/03/ESP-385-stormwater-wetlands-for-the-texas-gulf-coast.pdf

Shah MAR, Rahman A, Chowdhury SH (2018) Challenges for achieving sustainable flood risk management. J Flood Risk Manag 11:S352-S358. https://doi.org/10.1111/jfr3.12211

Sikorska AE, Viviroli D, Seibert J (2018) Effective precipitation duration for runoff peaks based on catchment modelling. J Hydrol 556:510-522. https://doi.org/10.1016/j.jhydrol.2017.11.028

Spiliotis M, Skoulikaris C (2019) A fuzzy AHP-outranking framework for selecting measures of river basin management plans. Desalin Water Treat 167:398-411. https://doi.org/10.5004/dwt.2019.24639

Stefanakis A (2019) The role of constructed wetlands as green infrastructure for sustainable urban water management. Sustainability 11(24):6981. https://doi.org/10.3390/su11246981

Survey UG (2020) Digital Elevation-Shuttle Radar Topography Mission (SRTM) 1 Arc-Second Global. Available online: https://www.usgs.gov/centers/eros/science/usgs-eros-archive-digital-elevation-shutt le-radar-topography-mission-srtm-1-arc?qt-science_center_objects=0\#qt-science_center_objects, Accessed on 15 Nov 2020

United Nations. (2015). THE 17 GOALS I Sustainable Development. https://sdgs.un.org/goals

U.S. Department of Commerce (2015) Flood and flash flood definitions; NOAA, National Weather Service, Eds

United States Environmental Protection Agency (U.S. EPA) (2020) Storm Water Management Model (SWMM). Available online: https://www.epa.gov/water-research/storm-water-management-modelswmm, Accessed on 7 Nov 2020

USD (1968) Urban Hydrology for Small Watershed. Available online: https://www.nrcs.usda.gov/internet/ FSE_DOCUME/stelprdb1044171.pdf, Accessed on 8 Oct 2020

van Wesenbeeck BK, Mulder JPM, Marchand M, Reed DJ, de Vries MB, de Vriend HJ, Herman PMJ (2014) Damming deltas: a practice of the past? Towards nature-based flood defenses. Estuar Coast Shelf Sci 140:1-6. https://doi.org/10.1016/j.ecss.2013.12.031

Vörösmarty CJ, Rodríguez Osuna V, Cak AD, Bhaduri A, Bunn SE, Corsi F, Gas-telumendi J, Green P, Harrison I, Lawford R, Marcotullio PJ, McClain M, McDonald R, McIntyre P, Palmer M, Robarts RD, Szöllösi-Nagy A, Tessler Z, Uhlenbrook S (2018) Ecosystem-based water security and the sustainable devel-opment goals (SDGs). Ecohydrol Hydrobiol 18(4):317-333. https://doi.org/10.1016/j. ecohyd.2018.07.004

Wakode HB, Baier K, Jha R, Azzam R (2018) Impact of urbanization on groundwater recharge and urban water balance for the city of Hyderabad, India. Int Soil Water Conserv Res 6:51-62. https://doi.org/ 10.1016/j.iswcr.2017.10.003

Water Resources Publication, LLC (2008) Hyfran-Plus Software. Available online: https://www.wrpllc. com/books/HyfranPlus/hyfranplusdescrip.html, Accessed on 10 Nov 2020

Wheater H, Evans E (2009) Land use, water management and future flood risk. Land Use Policy 26:S251S264. https://doi.org/10.1016/j.landusepol.2009.08.019

Yassen AN, Nam W-H, Hong E-M (2020) Impact of climate change on reference evapotranspiration in Egypt. CATENA 194:104711. https://doi.org/10.1016/j.catena.2020.104711

Yasser B (2017) 8 Villages in the "Bride of Upper Egypt" Are Waiting to Die in the Bosom of the Mountain 2017. Available online: www.elmogaz.com/353420. Accessed on 18 Dec 2020

Youssef AM, Hegab MA (2019) Flood-hazard assessment modeling using multicriteria analysis and GIS. Spatial modeling in GIS and R for earth and environmental sciences. Elsevier, Netherlands, pp 229-257

Youssef AM (2016) Analysis on causes of flash flood in Jeddah City (Kingdom of Saudi Arabia). Geomat Nat Hazards Risk 7:3. https://doi.org/10.1080/19475705.2015.1012750

Zalewski M, Janauer G, Jolankai G, Pypaert P (1997) Ecohydrology a New Paradigm for the Sustainable Use of Aquatic Resources. International Hydrological Programme. UNESCO, Paris

Zhu Z, Chen X (2017) Evaluating the effects of low impact development practices on urban flooding under different rainfall intensities. Water 9(7):548. https://doi.org/10.3390/w9070548

Publisher's Note Springer Nature remains neutral with regard to jurisdictional claims in published maps and institutional affiliations. 